Florida International University FIU Digital Commons

6-30-2015

\title{
The Central American Question: Nicaraguan Cultural Production and Francisco Goldman's The Ordinary Seaman
}

Oscar A. Gonzalez

Florida International University, ogonz020@fiu.edu

DOI: $10.25148 /$ etd.FIDC000075

Follow this and additional works at: https://digitalcommons.fiu.edu/etd

Part of the Latina/o Studies Commons

\section{Recommended Citation}

Gonzalez, Oscar A., "The Central American Question: Nicaraguan Cultural Production and Francisco Goldman's The Ordinary Seaman" (2015). FIU Electronic Theses and Dissertations. 2225.

https://digitalcommons.fiu.edu/etd/2225 


\title{
FLORIDA INTERNATIONAL UNIVERSITY \\ Miami, Florida
}

THE CENTRAL AMERICAN QUESTION: NICARAGUAN CULTURAL PRODUCTION AND FRANCISCO GOLDMAN'S THE ORDINARY SEAMAN

\author{
A thesis submitted in partial fulfillment of \\ the requirements for the degree of \\ MASTER OF ARTS \\ in \\ ENGLISH \\ by
}

Oscar A. Gonzalez 
To: Dean Micheal R. Heithaus

College of Arts of Sciences

This thesis, written by Oscar A. Gonzalez, and entitled, The Central American Question: Nicaraguan Cultural Production and Francisco Goldman's The Ordinary Seaman, having been approved in respect to style and intellectual content, is referred to you for judgment.

We have read this thesis and recommend that it be approved.

Bruce Harvey

Heather Russell

Ana Luszczynska, Major Professor

Date of Defense: June 30, 2015

The thesis of Oscar A. Gonzalez is approved.

Dean Micheal R. Heithaus

College of Arts and Sciences

Dean Lakshmi N. Reddi

University Gradute School

Florida International University, 2015 


\section{ACKNOWLEDGMENTS}

I would like to acknowledge and give special thanks to my friends and family who have been there to help me and encourage me throughout my undergraduate and graduate studies. I also thank the English Department staff, faculty, and my thesis committee members for a smooth, happy, and intellectually stimulating experience.

Finally, I would like to give especial recognition to my thesis director, Dr. Luszczynska, for encouraging me to think outside the box and for making me rethink how I approach literature and the world. 


\begin{abstract}
OF THE THESIS
THE CENTRAL AMERICAN QUESTION: NICARAGUAN CULTURAL PRODUCTION AND FRANCISCO GOLDMAN'S THE ORDINARY SEAMAN by
\end{abstract}

Oscar A. Gonzalez

Florida International University, 2015

Miami, Florida

\title{
Professor Ana Luszczynska, Major Professor
}

This study examines the cultural production and political history of Nicaragua from the 1960s to the early 1990s and interprets Francisco Goldman’s The Ordinary Seaman alongside Central America’s literary boom period, the nation-building project of the revolutionary letrados, and race relations between Nicaragua's Pacific region and its two autonomous sectors of the Atlantic coast. It is argued that Central American ways of seeing are colored by the interplay between a revolutionary past, the myth of the pure Indio or mestizo, and the erasure of national identity in the US contact zone. Rather than recuperating a Central American identity, it is maintained that exposing the construction of said identity uncovers the hidden blackness and the heterogeneity of the Central American isthmus. Ultimately, the thesis aims at giving visibility to forgotten and ignored Central American narratives, histories, and people, and stresses the significance of studying the region within a literary and black Atlantic perspective. 
TABLE OF CONTENTS

CHAPTER

PAGE

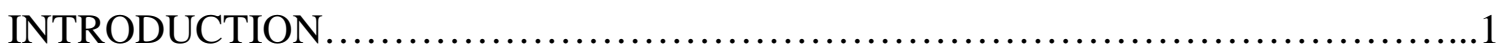

CHAPTER I: LOS LETRADOS: LITERATURE, NATIONALISM AND

SPATIAL/TEMPORAL CENTRAL AMERICAN WAYS OF

SEEING

CHAPTER II: THE ORDINARY SEAMAN AND THE CASE OF NICARAGUA'S ATLANTIC

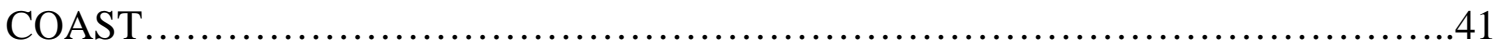

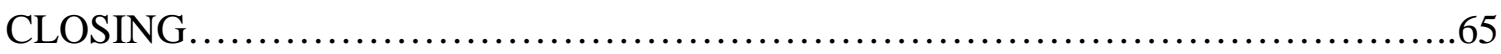

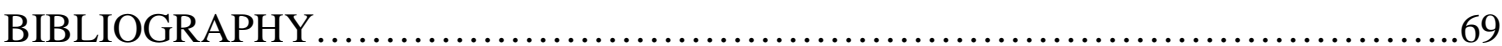




\section{INTRODUCTION}

In the wake of president Obama's November 2014 executive order, which grants temporary stay to approximately $45 \%$ of illegal immigrants, debates about immigration and border control have shone the light back on the nation's largest minority group, the Hispanic or Latino population. While it is true that this reform affects other undocumented immigrants besides Latino/as, it seems that special emphasis is being placed on the US-Mexico border. Indeed, it is not surprising that Obama's decision comes at a time when an unprecedented number of undocumented Central American children have crossed the US-Mexico border, pushing politicians to stop ignoring the problem (as they term it), and start making changes. More to the point, the United States' concern with immigration and its obsession with border control has resuscitated the Central American problem, which has been lying dormant since the eighties and nineties; namely, the relationship between the US and Central America.

Although the reappearance of Central America in the national spotlight might seem like news, interest in Central America is nothing new. Long before the Cold War and the US' interest in Central America as a stage of economic and political battles, the isthmus has been an exoticized and exploited land bridge, a center of first-world experimentation of every sort (political, economic, developmental, etc.). As Ana Patricia Rodriguez explains in Dividing the Isthmus: Central American Transnational Histories, Literatures and Cultures, its geographic and geophysical location served as a passage between north and south as well as a divider of the Atlantic and Pacific oceans: "the only region in the world whose geophysical landmass is both intercontinental and interoceanic” (5). As such, the isthmus has been and is a highly contested territory where 
European treasure seekers, conquistadors, and now economic world powers seek to establish control of this significant land-post. In recent history, the Panama Canal was an important project that allowed the US to stake claim of a major economic and political stronghold. However, now that a new Chinese-led canal in Nicaragua is said to be under construction, new debates and power struggles have emerged. Because the Nicaraguan canal is a Chinese-led initiative, it will be in direct competition with the US backed Panamanian canal. Indeed, the US embassy has voiced concerns over the new canal: HKND Group is controlled by a little-known Chinese mogul, Wang Jing, who has said the Chinese government is not behind the project. But his reluctance to reveal his financiers has led many to speculate he enjoys Beijing's tacit backing. China's involvement would be a direct challenge to the Panama Canal, which was controlled by the United States until 1999. The canal would also give China a major foothold in Central America, a region long dominated by the United States (Reuters New York Times)

The US has had control of the region for over a century now, and it will hardly lose it that easily. While debates over the construction of the new canal in Nicaragua are usually centered on the ecological disaster it will cause versus the economic benefit it will allegedly produce, the Nicaraguan canal is also a symbol of power; therefore, the US is extremely concerned that China will have control of the canal.

The construction of the new canal has caused protests in Nicaragua where according to The New York Times twenty-one people have died in the violence between police and protesters. This is yet another reason why the isthmus is becoming increasingly important to notice. It will be interesting to see how this canal will affect 
foreign policy and relationships in Latin America. If history proves to be a prophet, we are sure to see US intervention once again. The US has meddled in Central American for as long as they became a world power. While US intervention in Central America had retreated from the national spotlight after political stability seemed to be a given in the isthmus, the American footprint has always been stamped there in ways that become relevant to those, like myself, who inquire about identity politics in its Central American variety.

I will admit wholeheartedly that I am personally invested in this project. If anything at all, my project aims at shedding light on alternative Central American ways of seeing that have been silenced and obscured through various means. To explore how the isthmus has become a silenced and forgotten space, my first chapter explores the isthmus in general. I argue that the tie between literature and politics, global capitalism, and the revolutionary crisis of the 1970s and 80s contribute in creating a deceptively homogenized Central America. I offer a survey of Central America's literary boom period, which I demonstrate to be invested in a nation-building project during the revolutionary process. I then approach the construction of Central American identities through a critical space-time theory that looks at how temporal/spatial ruptures offer modes of expressing varying Central American ways of seeing. Finally, I end the chapter by exploring how Francisco Goldman's The Ordinary Seaman articulates the tension of contested identities in the US contact zone.

In my final chapter, I aim at deconstructing the idea of stable Central American identities by looking at the specific case of Nicaragua. In it, I consider racial constructions and suggest that any worthy scholarship of Central America should 
consider the silenced and ignored Central American black Atlantic diaspora. A significant interpretative move I make is reading Goldman’s text, a supposedly “Latino” novel, as a black Atlantic text. I end the chapter by suggesting that Goldman's novel exposes fixed ideas of "blackness" by blurring racial lines.

It should be noted, however, that there are other Central American-American novels besides Francisco Goldman's The Ordinary Seamen. Furthermore, by choosing to only interpret Goldman's text, I am not suggesting that Goldman’s text is representative of the Central American-American novel. I choose it because it fits well with the case of Nicaragua. Nevertheless, I understand that it is one of many Central American-American texts that should be read alongside historical and cultural expressions, which contribute to the way Central America constructs and deconstructs identity. However, it is vital that I provide the reader with some historical context first. To emphasize the significance of Central America and to set the stage for the chapters that follow, this introductory section will survey the history of US intervention, ideology, and policy making in Central America.

Consider, for example, the role of the US in the isthmus since the early twentieth century starting with the Roosevelt administration. According to Mauricio Solaun, in US Intervention and Regime Change in Nicaragua, the Roosevelt administration found justification to place boots on the ground through the international pro-democratic Tobar Doctrine in which all Central American countries signed international treaties that condemned any government that was a product of force. According to Solaun, the US policed the isthmus to prevent countries from becoming part of the communist wave. They feared that if the Central American nations did not adhere to the treaty, European 
powers would intervene. Therefore the US decided to become more active in the region. The US felt that they had to intervene because of “...the brutal wrongdoings and weakness of Latin American governments [which] affected US interest. And...the source of this alleged 'indecency...[was] the absence of democracy!” (Solaun 16). We see since the outset an imperial/colonialist attitude toward the nations and people in the isthmus. They are deemed too weak or brutal. Their governments need intervention because they are not democratic in the Western sense. The way the West imposes its ideology on thirdworld countries is telling because the type of ideology and policymaking that the US pushes forward directly impacts the way Central American people view their individual and national identities. Too often, Central Americans craft their national identity in relation to US dominance.

Crucial to understanding this US attitude is what Solaun terms realpolitik and democratic crusades. According to Solaun, realpolitik is a political stance that creates foreign policy from the standpoint of national interest. Nevertheless, realpolitik's rhetoric conceals the fact that US intervention forces a Western form of democracy on foreign countries like those in Latin America whose cultural and political context vastly differs from that of the Western world. According to Solaun, US governments, which favored realpolitik, waved the democracy flag to justify intervention. They would spew nationalistic rhetoric to convince the public that it was in the "American" people's best interest to intervene. Intervention for US national security is a common example of this. Democratic crusades, on the other hand, utilize the human rights banner to justify intervention and make democratization a political goal (Solaun 9). Yet, neither realpolitik nor democratic crusades operate individually. What occurs in Central America is a 
combination of the two where a democratic crusade is masked in realpolitik ideals, especially when the US intervened in Nicaragua during the Somoza regime of the 1960s and 70s.

The United States justified intervention via their political maneuvering and by extension the US dominated the isthmus. For example, in Nicaragua, the international treaty allowed the US to oust the Somoza regime in the 1970s. Through economic sanctions, a popular and supposedly peaceful manner of effecting regime change, the US sought to rid itself of Somoza even though a few years prior, he had been their friendly client. But what was supposed to be a peaceful democratic transition of power became a bloodstained revolution. The Sandinista front with the backing of other Latin American countries, including my country by birth, Costa Rica, wage armed rebellion against Somoza’s authoritarian regime.

Intervention did not stop there. Unsatisfied with the government that resulted from the revolution, in the 80s the United States sought to remove the Sandinistas, a communist regime. Even though at first the US aided the Sandinistas in removing the Somoza dictatorship, they were not expecting for the new Sandinista government be a communist regime. While the revolutionaries successfully gained power in Nicaragua, the Sandinista’s ties with Soviet-Cuban communist regimes signaled an inevitable US military intervention even if only through the arming of the Contra front that would fight against the Sandinista communist regime. Nevertheless, the Sandinista government was able to maintain power till 1990, at the end of the Cold War, when free elections allowed Violeta Chamorro to ascend to the presidency. 
What I attempt to show through the historical narrative is the degree to which ideology determines policymaking, and how this in turn affects the relationship between people and their imagined communities. The US has no justifiable excuse to intervene in the affairs of Central America. In fact, it is obvious that its main goal is to maintain sovereignty over the region. Given the history of colonialism in the area and the ways in which foreign policy continues to affect the welfare and autonomy of Central American nations, it is not difficult to see the relationship between intervention and oppression. As Solaun demonstrates, the US as the world power establishes relations with other dependent countries like those in Central America and in so doing exerts power over the region. While the US wants to "democratize” the region, international clientelism, an economic exchange in which smaller nations become dependent on world powers for their subsistence, creates a hierarchical oppressive structure. Understandably, a client-state like Nicaragua might view intervention as a form of coercion, and rightly so. Through intervention the US seems to be modeling an international authoritarian regime masked under the veil of freedom and liberty. In reality, however, political strategies evince colonialism in that they seek to control Central America through policies, loans, and economic sanctions that keep these small nations impoverished because they can never pay off their debts, making them always dependent upon the US. As is the case of the isthmus in general, Nicaragua is a space of oppression, poverty, revolution, and false liberation, and it is at the expense of ordinary people that political battles are fought. Political elites (whether with malice or good intention) have made people like me lose faith in any government's ability to improve Central America's impoverished condition. However, it is not my intention to find solace or to speak 
nostalgically about my former country. For me, any mission of self-discovery is as useless as any simplistic attempt to resolve or place blame on this or that political party. And, as the chapters that follow deal with identity as a fluctuating singular-plurality where culture is contested and imagined, but where real people with real histories ethically depend on one another, I will provide my personal testimonio. In providing my story, I do not wish to push for any political agenda, instead I aim to give voice to individual stories and how identity is constructed within Latino/a American contact zones. In short, I hope to create a modest revolución within literary studies, as I feel that Central American-Americans have for too long been ignored within Latino/a studies.

My family and I have personal experience with revolution, with border crossings, and with what I can describe as an ambivalent sentiment about my ex-countries and my ever changing imagined cultural identity. I was born in the late seventies in San Jose, Costa Rica, to Nicaraguan parents. My parents were forced to flee Nicaragua in the wake of the revolution. Fleeing the war, my parents decided to migrate to Costa Rica. Returning to Nicaragua once the Sandinista National Liberation Front (FSLN) overthrew Anastasio Somoza Debayle in 1979, ending the Somoza dynasty, we found ourselves in peril once again, as US intervention attempted to destabilize the growing communist wave in Latin America.

The Contra-Sandinista wars were fought and masked under the people’s rights and under the UN's definition of human rights, but these wars had little to do with us. As my father once told me, these ideological and political wars are fought by government elites behind their wooden desks and their large leather chairs. The people, who often do not know why they fight, fight the real revolution. People die. New governments rise 
thanks to US intervention, yet look at what that did for us. We had to flee our home. Revolution is often necessary, but it is also dangerous, and it is disturbing to know that one's family member is risking his or her live for abstract ideals that in the end would not change one's living conditions. My immediate family was fortunate compared to others. Some people, like my uncle, were forced to take up arms. According to the stories my father tells me, people were struggling to put food on the table, while the government elites fattened their pockets at the expense of ordinary people who were sent to fight "por la patria,” so that they could stay in power.

My father has no problem saying that he hates Nicaraguan politics (and politics in general) and wants nothing to do with it. His bitterness towards his former country is fueled by what he witnessed. It was the fear that my father and older brother would be recruited by the Sandinistas to fight against the US supported Contra that caused us to flee Nicaragua. Ordinary people like my parents did not ask for war or for revolution, instead they sought economic stability and safety. And thus, for a second time, we "illegally" crossed the border, but instead of crossing the Costa Rican/Nicaragua border, this time we sought refuge in the US.

It was the revolution that led us to where I was born but it was the outcome of la revolución that led us here (U.S.A). That is why, when I hear it or read about it, the word revolución resonates with me. It is a word that points towards a messy time in my life, a time of ambivalence. I was just a kid. I hardly remember the details. But I do remember my uncle with his army-green uniform and his Ak-47 although I never saw him fire it. I also remember the car ride to the bus station, the bus ride, and our stay in Matamoros, Mexico. 
We crossed the river. A church, in El Paso I believe, which hid illegal immigrants, took us in. Finally, a family member paid for our bus fair to Miami where I started school in Halloween of 1986, a fitting date. It was a scary time, a time that showed me how to mask my status.

In school I had to cross a new border. It was the first time that I considered my identity as something that mattered. I never cared about it before, but here in this strange new place, I was forced to. My experience with ESOL classes taught me that I was different, an alien without a mask. I needed to learn English as soon as possible: “no Spanish” said the teacher. "English here. De adonde to eres? Are you Mexican?” asked a voice. "Nicaragua. Sandinista?” “Me llamo Oscar soy de Nicaragua.”

The crazy thing is that once I learned English, I was uncomfortable with Spanish. No Spanish. Revolución. You are illegal. As I felt more at ease in the US, I no longer remembered. I had to conjure up these memories. “How is Nicaragua?” my Dominican friends would ask me when I was a teenager. “I do not remember,” I would say. And now, as I sit here remembering I realize how much I’ve changed.

My story is one among many during the eighties where not only Nicaraguans, but other Central American people such as Hondurans, Guatemalans, and Salvadorians left the war infested zone seeking political refuge. Yet, not all received political asylum. Interestingly, “although the United States led a decade-long economic blockade and ‘contra-revolutionary’ war in Nicaragua and granted some (not my family) Nicaraguan immigrants political asylum from the Marxist Sandinista government, Salvadorans, Guatemalans, and Hondurans in flight from right-wing military dictatorships and war conditions funded by the United States were not granted political refugee status” 
(Rodriguez 388). The fact that these were right-winged dictatorships might have something to do with why only those who came from communist regimes were granted political asylum, for US intervention during the Reagan administration was largely fueled by Cold War politics that sought to destabilize what they perceived to be a threat to rightwing capitalism. If it was true that the US intervened to help the people of Central America, then Guatemalans, for instance, would have been granted refuge as well, but to do so would have meant to admit that the US intervention failed and that right-wing politics are susceptible to the same corruption as the left-wing revolutions they sought to undermine:

In Guatemala and Nicaragua, prolonged armed conflict and U.S.-led covert operations conform to world systems theory's military links hypothesis, which holds that military interventions undertaken by core nations to protect overseas investments and guarantee free trade inevitably establish ancillary social and political ties...At the same time, intervention plants seeds for future violence...by distributing arms, materiel, and training to large numbers of people whose violent acts subsequently disrupt local markets (Alvador and Massey 139).

Indeed, it is not left-wing politics that is to blame for the Central American crisis, but global capitalism and the United States' need to maintain economic power in the region.

US intervention and the idea that Central America is a region in crisis are largely responsible for imagined Central American-American identities. That is, people who migrate from Central America to the US often view their identity in relationship to “American” supremacy. Many see the US culture as superior and often feel the need to 
assimilate quickly because of the stigma associated with being from Central America. However, there is no such thing as a universal Central American culture. That Central America is a space of unstable national identities haphazardly grouped together, and that outsiders usually envision it as one unit, reveals something significant. While it is true that the region has historically been plagued by political wars and dire economic conditions, Central America is, nevertheless, a catchall phrase that renders the heterogeneity and political complexity of individual countries invisible, and by default complicates modes of representation and identity politics in the region and in the U.S.

Besides the discomfort and ambivalence that people both inside and outside Central America often feel about their countries of origin, an unstable nationalistic identity caused by US intervention and revolutionary struggle might explain, as the prominent Central Americanist Arturo Arias suggests, why some Central American immigrants are silently lumped into existing U.S. Latino/a categories, such as "Mexican,” for example. The instability of the region and the fluctuating migratory patterns complicate nationalistic notions of identity. That people arriving from Central America do not form a unitary cultural mass because mestizaje and racial hybridity destabilizes the “Central American” catchall phrase, is a possible reason why Central AmericanAmericans have been largely ignored within the U.S. Latino/a literary tradition.

Any political discourse, whether within the US or within Central America, which attempts to speak for a given group, inevitably silences and homogenizes individual voices, voices of ordinary people whose lives have been affected by the ways in which Western ideology has constructed their being and by extension their ability to act as agents of their singularity. The overall point of my thesis is that Central American 
narratives and Central American ways of seeing present complex and ever expanding cultural expressions that can no longer be ignored.

It is vital to not overlook how “Central American” narratives contribute to our understanding of cultural formations in general, and within US “Latino/a” literary studies and black Atlantic scholarship in particular. The argument that Central Americans are too small of a group to speak about in detail is not a viable excuse for not studying the region within black Atlantic or US Latino/a literary studies. In fact, demographic numbers confirm that Central Americans constitute approximately eight percent of the US population or approximately 3.1 million, without including unaccounted for undocumented immigrants. And, as Sarah J. Mahler and Dusan Ugrina demonstrate, “The region's marginalization in the world economy and growing populations assure that migration will remain an enduring feature of Central American life into the foreseeable future” (“Central America: Crossroads of the Americas”). Given that Central Americans make up the larger part of undocumented Latin American immigrants and given that this sector of the population is the fastest growing population within the "Latino/a" community, Latino/a studies has a huge blind spot to fill in. There needs to be a more thorough and inclusive study of Central American cultural expressions that necessarily must include Central America's Atlantic coast if we are truly to allow the isthmusian heterogeneity to speak. Interestingly for us today, Obama’s recent decision makes the exclusion of Central American narratives even more problematic. As new faces come out of the shadows, the all too comfortable Latino studies' understanding of Latinidad begins to be contested. 


\section{CHAPTER I: LOS LETRADOS: LITERATURE, NATIONALISM AND}

\section{SPATIAL/TEMPORAL CENTRAL AMERICAN WAYS OF SEEING}

Using Francisco Goldman’s The Ordinary Seaman as a vehicle to speak about Central American ways of seeing, in this chapter I hope to show the intertextualtransnational and spatial/temporal construction of Central American identities. To do so, I begin by outlining literature's role in Central America so as to show how imagined Central American identities are constructed by a geographically specific literature in response to revolución. I end the chapter by focusing on the re-imagining of Central America from the perspective of a post-revolutionary Central American-American novel like Goldman’s The Ordinary Seaman.

Guided by Benedict Anderson’s concept of “Imagined Communities,” I argue that Central American ways of seeing construct identity vis-à-vis the concept of la patria. Central America as such is a type of nationalism constituted by the intertextual apparatus at play between politics and literature and the subsequent crisis that ensues. As evidenced through Arturo Arias exposé of the Central American literary boom period from 19601990, revolution and literature work together to create a Central American nationality through a four-step process. This imagined nationhood is pushed through 1) literature that anticipates revolución, 2) literature that responds to revolución, 3) newly formed regimes that use literary heroes (los letrados) to construct a new national consciousness, and finally 4) through the removal or reconfiguration of socialist regimes at the end of the revolutionary period. The result is a national identity contingent on a revolutionary past that new regimes struggle to forget in their efforts to mimic neo-liberal, "first-world" nation-states. This mutable and contested nationhood is further displaced by immigration 
and the emergence of competing "Latino" Spanish-speaking identities in the US contact zone.

La revolución, violence, poverty, immigration and the political battles that result from the 60s to date have tainted many people’s view of "Central America.” Strictly speaking, Central American identity is necessarily linked to crisis and immigration. This conceptual framework has homogenized the region’s people. Central America, as such, is not a geographical place where various everyday people exchange ideas, interact and create their own experiences, but a conceptually fixed space associated with a revolutionary past that erases the complexity of cultural interactions. It is this geographical and temporal placeless space that immigrants arriving to the US carry with them, an identity marker at once ephemeral and materially "over there.” When most think of Central America as such, however, that place "over there" does not include all the nations in the isthmus stretching from Panama to Belize. The Western gaze sees "Central America” incased between the boundaries of Costa Rica and Mexico to include only the countries of Nicaragua, Honduras, El Salvador, and Guatemala.

The geographical encasement and temporally fixed space that is imposed after la revolución, points to a Foucaultian rupture that exposes the construction of the term Central America. By temporally fixed, I mean that "Central America” as an identity category and a nationalistic concept is stuck in the past because it has never been able to lose itself from its revolutionary history. Moreover, the Central American literary boom period and its letrados, as I will shortly demonstrate, attempted to nurture what Foucault terms "the hidden presence of the sacred" (23). The hidden sacredness involves the dialectic relationship of spaces and places. In plain English, spaces and places differ in 
that places necessarily evoke memories and emotions. A place as memory constructs the experience of a space. Space, on the other hand, is devoid of emotions and memory. A space can simply mean an encasement, one’s spatial surroundings, which can create a certain kind of experience, but a space only becomes a place once emotions and memories are added to it. A person always-already situated within space and time, whether within the sacred space of the body that must be preserved or the sacredness of a place thought of as "home,” is constituted by his or her temporal/spatial interactions. Is not nationalism the construction of a geographical space into a sacred place? All nations contain within their boundaries sacred spaces and symbols that assemble the ideas of places. The sacred dimension is nationalism at its purest, which is accompanied by the utopian dream of the revolutionary poet. That is, los letrados aimed at creating a new national consciousness through symbols that forged a shared cultural origin and promised future national prosperity. That the revolution is never able to materialize its utopian dream suggest that "repairing” the isthmus is not merely a utopic but a heterotopic dream: Between utopias and these quite other sites, these heterotopias, there might be a sort of mixed, joint experience, which would be the mirror. The mirror is, after all, a utopia, since it is a placeless place. In the mirror, I see myself there where I am not, in an unreal, virtual space that opens up behind the surface; I am over there, there where I am not, a sort of shadow that gives my own visibility to myself, that enables me to see myself there where I am absent: such is the utopia of the mirror (24)

Foucault's vision is useful in that the utopia of the mirror is the utopia called Central America, an “imagined community," as Anderson suggests, which reflects the 
relationship between the four aforementioned countries. The mirror is also that which points to a place once called home, an imagined place that is geographically and historically constituted by crisis, but which also evokes a utopian dream because of the sentimental value associated with home. The place that is at once "there" and not "there" is perhaps one way in which Central American-Americans experience place, as a utopian mirror or a placeless temporal/spatial location that constitutes an imaginary self.

There in the imagined image stands the "place" of los letrados. According to Arturo Arias Taking their Word: Literature and the Signs of Central America, in the 1960s a new way of imagining Central America begins. As Arias suggests, a change in the way regional writers expressed themselves in wake of the revolution influenced by experimental forms of writing from abroad, leads los letrados (men of letters) to moved away from the traditional "realistic" novels to "the new tendencies," which departed from "social realism" (Arias 9). Because social realism is connected to the Soviet Union, the move away from this mode of writing is not only literary but also political. That Central American literature broke from social realism also signals a break from Soviet Union communist propaganda in favor of "the Cuba model that attempted to implement Guevara's teachings and theory” (9).

Arias claims that during the decades of revolutionary turmoil, politics and literature were two parts of the same coin. Los letrados wanted to create Literature with a capital $\mathrm{L}$, and used it to construct their national identities, despite the low literacy rates in Central America. "High culture" literature was possible thanks to government sponsored printing houses that backed los letrados because those in power saw literature as a weapon for pushing their political agenda. The deliberate push was an attempt to 
restructure a nation in opposition to capitalism. While Anderson suggests that "the convergence of capitalism and print technology on the fatal diversity of human language created the possibility of a new form of imagined community," Arias points out that los letrados, as nation builders, used print technology and the construction of a supposed shared Maya or Mestizo heritage to create unity and oppose the West (Anderson 46). Los letrados sought to build a legacy and reconstruct a national consciousness, often through romantic notions of meztizaje. However, they failed to account for the black Atlantic and the different languages spoken there, like English and Miskito, in their idea on nationhood. Los Letrados pushed for a Spanish-speaking literary rich national identity and saw it as their ethical duty to speak for the people.

These men of letters believed that "To be a writer is to be the moral consciousness of the people” (8). They continued their nation-building project during the 1970 s as they influenced the political landscape of the isthmus. However, a light shift in narrative form took place. It was now more important to have a narrative voice as plot became less central, and “language became a form of representation in itself” (Arias 11). Interestingly, decades before the publication of Doris Sommer’s Bilingual Aesthetics, a text that suggests bilingual and multilingual language games upset the homogenizing force of monolingualism, Arturo Arias points to a similar aesthetics in the Central American novel as early as the 1970s. Arias suggests, this type of language game played a vital role in creating the idea of a mestizo nationalism. Indeed some good work was done in that Maya literature subverted the Castellano dominated narratives of previous years. As Arias claims, the insertion of this type of Maya language as well as culturally specific lingo illuminated pockets of society that were rendered invisible by the high art 
of the previous decades. However, it failed to account for other languages, such as Creole, English, and Miskito. As I will show in the next chapter, while mestizaje and a shared Mayan cultural can be a subversive concept, it can also silence other ways of seeing.

Perhaps los letrados had good intentions. Nevertheless, it is evident that the “illusion of avant-garde writers as equivalent to avant-garde revolutionaries” (13) creates a disparity between the elite middle and upper class and the "lower" classes they sought to represent in their narratives. The problem is that "their narratives attempted to constitute an ideological basis for revolution as an implicit justification for the constitution of their own selves as revolutionary leaders” (Arias13). The issue with the boom period is that literature took part in a type of naming and knowing game that, perhaps unintentionally, silenced the subaltern subjectivities it sought to empower. In this naming and speaking, los letrados defined the identity of the revolutionary community.

However, it is important to note that the exclusionary practice of nationalism and its relationship to literature does not necessarily operate with an idea of hatred of the Other or any antagonistic language. As Anderson notes, nations sometimes inspire love. They create patriotism through symbols and national heroes. In this manner, los letrados wanted to be national heroes and create a kind of patriotism that was "profoundly selfsacrificing” through "the cultural products of nationalism—-poetry, prose, fiction, music, plastic arts [etc.],” which is evident in the literature produced during the boom period (Anderson 141). Indeed, Los letrados sought to produce "subjective notions between place and self, between self and meaning in Central America...texts are vehicles that...articulate those symbolic traits that mark the subjects' cultural imaginings, 
or... 'emotional memory' of a region” (Arias 3). The aesthetics fashioned by Los letrados creates an “imagined community” that produces, to use Benedict Anderson’s terms, "simultaneity" and the "meanwhile" in "calendar time," 1 as the shift from religion as a major organizer of national consciousness dissipates in light of the new Marxist regimes that the revolution reproduces.

As in Anderson's assessment, los letrados speak to Central American "fellowreaders, to whom they were connected through print, formed, in their secular, particular, visible invisibility, the embryo of the nationally...” imagined Central American community (Anderson 44). And, as Arias proposes, this community is fabricated through the literature of the period in which "a singular social group is constructed from dialogues, monologues, and fragments of writing or speech that form a sort of chorus of dissimilar voices and discourses that gradually come to constitute a representation of a certain sector of society at a given point in time” (Arias 11). In other words, these types of language games became a tool for emancipatory projects that reconfigured cultural identities and imagined communities through Anderson’s “calendar time.” For example, the headline of La Republica, a Central American newspaper, might read “Tuesday, 19 July...Somoza derotado;” as a result, the shared national newspaper creates "simultaneity" in "Calendar time" and connects people across Central America who wake up to the headline "Somoza is defeated." Those major events, and even the minor ones,

\footnotetext{
${ }^{1}$ In Imagined Communities, Benedict Anderson claims that simultaneity and calendar time are constructed through national narratives via the publication of national newspapers and the serialization of novels within them. These narratives create a feeling of connectedness among people within the confines of a given nation. Anderson suggests that simultaneity is felt when a person imagines other people in his/her imagined community reading the same newspaper during the same calendar time. Anderson refers to this calendar time as "homogenous empty time" (24). It is empty time because it is experienced without the sacred dimension of Messianic time. In line with Walter Benjamin's idea of Messianic time, which Anderson refers to as occurring during the "dynastic realm," Anderson states that Benjamin "rightly stresses that such an idea...is wholly alien to our own view” (24).
} 
become part of the national consciousness through the proliferation of print media and the avant-garde writer's response to the revolutionary context, as los letrados produce national symbols, and push for their nationalistic visions after the ousting of Somoza.

The cultural imaginings and the fighting spirit of just a few years earlier began to shift in the1980s, however. Crucial to one of the points I am making about Goldman’s text is the fact that while he wrote it in 1997, the novel is set in the 80 s where the two main characters are having to cope with the aftermath of the revolution. At this time, Nicaragua becomes somewhat peaceful. Elsewhere, (Guatemala and El Salvador) peace talks suggested that the revolution there was also coming to an end (Arias16). With the shifting of power in the region, los letrados set to rebuild new national identities: "The nation-building policies of the new states [instilled] nationalist ideologies through the mass media, educational system, administrative regulations and so forth” (Anderson 114). The new Sandinista government, for example, set forth a literary campaign that sought to educate the masses, but also included Sandinista ideology through the educational system and the national literature they enforced. According to a report by the United Nations Educational, Scientific, and Cultural Organization (UNESCO):

The National Literacy Crusade that took place in Nicaragua from March to August 1980 was probably the biggest venture of the Sandinista rule (1979-1990) and without a doubt the most important event within the reform of the education system. A decree was issued declaring 1980 the 'Year of Literacy.' The new government leaders saw literacy as an integral part of national development...literacy was seen as a part of the 
preparation of the whole population to manage the big task of national reconstruction...(Hanemann 2-3)

While it cannot go without saying that the Sandinista government sought to empower its citizenry, one cannot neglect the fact that it was convenient to their national ideology to turn the masses into readers, for increasing the readership would further establish their dominance.

However, as Arias contends, towards the end of the 80s, we can note a shift from strictly political themes to the testimonio novel that expresses the dissatisfaction of the revolution. There was a feeling that the chapter on the revolution needed to come to an end. What emerges out of these characteristically apolitical testimonios is a realization of the limits of language to capture the aftershock of post-revolution, post-war society and the dissipating influence of the letrados in the construction of nationhood. As such, the 1990s reflect the tension between previously held notions of literature's transformative and nation-building power and the climactic event of simultaneously severing and reassembling a post-revolutionary national identity.

In the 90s, the death of los letrados was eminent, finally to be entombed by the emergence of a "modern" nation-state that globalization and neo-liberal policies initiate. According to Stephen Henighan, "the Sandinista electoral defeat, marks the moment of rupture...the shattering of the organic idea of nation that was implicit in the words of [los letrados] when they spoke of 'mi patria' and 'mi pueblo'” (739). Henighan also points out that the governments since the electoral defeat of the Sandinistas have deliberately worked to eradicate the history and memory of Sadinismo by visibly changing the landscape of the capital Managua, Nicaragua. 
Visiting Managua today one becomes aware of the botched attempt to mirror the urban spaces of industrialized, commercial-oriented cities in the US where social stratification is evident. "Restaurants and shopping malls give the appearance of a modernized place...offer[ing] urban elites safe destinations when venturing from closely guarded homes...signal[ing] efforts to construct a new national identity centered on consumption” (739). But when one moves away from the center, the disparity between rich and poor is clearly visible. There is a kind of spatial turn that occurs after the defeat of the Sandinistas that constructs a Central American imaginary in relationship to place and the illusion of progress.

In a similar fashion, literature is in a way transported to a new market “place.” It must adapt to the changing capitalist landscape and move beyond the Central American borders. Neo-liberal policies change Central American literature from nationalistic narratives to a globalized consumer-centered literature. As such, Los letrados lose their iconoclasm with the disappearance of government sanctioned presses. Indeed, neo-liberal market economies in Central America force national writers to seek publication from publishers in the Spanish and the Mexican market (Henighan 740). Thus, the national writer must appeal to global markets where publishing houses only "export to those countries where they predict a market for at least 3000 copies to exist” (740). Therefore, Central American authors necessarily must write to a different audience and beyond the political realm they enjoyed previously.

The purpose of delineating this narrative arc, from the 60s till the 90s, besides demonstrating nation-building at work, is to link this period to Goldman’s text, which can be read as a post-revolutionary re-imagining of Central American ways of seeing. The 
novel begins in Nicaragua and describes a ghostly desolate city, "that invisible city of sprawling night that didn't seem to have any center” (3). One of the first images sets up a date, time and place: Sandino Airport, Nicaragua, "nearly three in the morning” two years after the revolution (3). Through the setting, the narrative sets up a doubling between the beginning and the end of the novel.

In the beginning we see a type of nationalism being forged in the description and imagery. Esteban presents the reader with the image of the fallen soldier that later is given a chance to redeem himself in the ship. We also see what Anderson calls simultaneity, "in which simultaneity is, as it were, transverse, cross-time, marked not by prefiguring and fulfillment, but by temporal coincidence and measured by clock and calendar” (Anderson 24). The temporal and spatial connection between the readers who can identify with that place and time and the discontinuity created by those who cannot, sets up boundaries akin to nationalism. It is, however, Esteban that must learn to cross those borders and present himself as a symbol of trans-nationality and later panethnicity when he enters the US contact zone. Through the temporal and spatial crossing that Esteban later traverses and the disappearance of the characters that anchor Central American ways of seeing, the novel mimics the construction and deconstruction of Central American nationalism as explored in my section on the boom period.

The reader also receives the imagery of Doña Adela, a lady from a job agency, who wears "a white blouse with the English words over the followed by a colorful little rainbow" (5). The imagery of Doña Adela is juxtaposed to that of Esteban, the protagonist and the guerillero as national hero, for whom this job signals a postrevolutionary imagining. “Today you start a new life,” he says to himself (3). Esteban’s 
description is quite revealing and symbolic. It is almost as if the narrator is describing a flag:

Esteban was the tallest of the five...his build was so slender and bony that his jeans and white, short-sleeve shirt tenuously hung from his hip and collarbones. He wore the same pair of black combat boots that had accompanied him through two years of war (6)

Esteban is described as tall and slender and his clothe drape like a flag half hung. However, he is also described as bony and wearing the same boots for two years even though the war is over.

One way of reading this passage is by seeing Esteban as a letrado who must deal with the fact that he is no longer a revolutionary: “ 'I was in a BLI,' said Esteban...He was sure he saw respect still their expressions like a fleeting shadow...He [felt as if he] didn’t have to say anything more... 'Maybe the war's over' said the former aircraft spotter. 'Maybe,' said Esteban neutrally” (7). Another way of reading this passage is as the death of the old and the birth of the new. But, there is a problem with this reading, namely in how to define the parameters between old and new. What is the difference between the old and the new? In this sense the novel is a step beyond the boom period both temporally and spatially. While this novel is not a "Central American” novel as such because it is written by a Guatemalan American author, and for the most part is set outside of Central America, it nevertheless imagines a Central American past and looks beyond it to express the aftershock of revolucion and the way in which the crew's stories go beyond it. That is, even though the novel is about Central American men, their stories are transnational. They are people stories that outweigh national ties. 
The novel is about the sharing of stories and how these stories associate people from different Central American countries to create a transnational consciousness. It is a transnational re-imagining of the isthmus within the contained space of the Urus, an abandoned ship in a Brooklyn port. The Ordinary Seaman portrays the stories of fifteen Central American men from Honduras, Nicaragua and Guatemala who are illegally hired by Americans, Capitan Elias and Mark. The men are set to work for the Urus, and are told that they will get paid and the ship will sail once they repair it. However, this proves impossible and Capitan Elias and Mark abandon the men. They find themselves stuck in the rusty, rat-infested ship with little rations, expired visas and no money to leave.

For a while the men cope through stories of desire, lust, and a glorious past, as Esteban's shared dream of la Marta, his ex-girlfriend who is killed in the war, weaves in and out of the narrative. Despite the crew's effort to repair the ship, their despair is monumentalized by the concept of this ship as metaphor for Central America. The sharing of stories, of Esteban and the men living in darkness, stuck in a ghost ship, points to how space and time converge to construct the crew's identity. This entrapment between boundaries, in a stateless ship with a flag of convenience, mimics the way in which the revolution and the US' portrayal of Central America as a problem or crisis, a heterotopia in crisis as Foucault suggests, causes the entrapment and concealment of people and by extension the concealment of differences.

Indeed, concealment is a major trope in the novel. The crew is not only trapped in the Urus, they are also concealed from the world beyond its borders. That the novel's first interaction between its central characters begins with Bernardo, el viejo, telling Esteban to "leave this shitty country behind" and that he later encourages Esteban to 
leave the ship as well, suggests that Bernardo sees the same Central American story repeating itself in the Urus (5). Can we not read the Urus as an allegory for nationalist and trans-nationalist conceptions of the isthmus? I read The Ordinary Seaman as a novel about the desire to move beyond borders and the frustration that results from not being able to move.

Perhaps the ocean and the crew's desire to sail offer a possibility to see beyond the boundaries of nationhood if only through the imagination of the stories they tell. The possibility of being at sea ruptures static identities through the crosscurrent of the ocean and the port cities of which the men dream. While nationhood is built on shared dreams and imagined connections, the men's stories are at odds with the homogenous experiences that nationhood fabricates. Unfortunately, their dreams are frustrated by the Urus because it never gets repaired and the crew never sails. While it is never achieved, the trope of the sailor and the sea makes visible the possibility of moving beyond the nationalistic images of the fenced off countries inland. Borders are claims of ownership masked under a shared destiny, but nobody owns the ocean. To say I am a seaman is to say I move freely through the world. Perhaps that is the dream of Central American immigrants that are legally and physically restricted from moving beyond the concealment of the stagnant ship called Central America.

Another way in which the novel thematizes spatial/temporal contingencies is through the memories of Esteban and the frustration of not being able to be aroused by the dream of his sexual experience in Quilalli, Nicaragua. Esteban is overcome by thoughts of war and a past that blots out the happy memories of his lovemaking. He looks at Bernardo and thinks, “In another half century he'd be this old waiter's age. Puta, would 
it stop then? This death blotting out love whenever he tries to conjure up love...Was there a girl who was going to bring love back to him...who was waiting for him now in a shimmery haze of hot city and ocean air without even knowing him yet?” (12). Several things are occurring in the text that hint at the imprint the past has on Esteban and the crew. The tension between the past and present is portrayed as both temporal and spatial interruptions that create a double consciousness.

The tension between the past and the present creates a double consciousness, two worlds, two time zones, a traumatic past coupled with a present that is no better, which brings about a particular way of seeing. It provides a framework for an imagined Central American-American identity in relation to a dreamlike or nightmarish past predicated on revolución. Added to this past is a present in an alien landscape that fails to recognize the legitimacy of the men's existence. Their existence is constituted by a phantom past that constantly haunts them, especially Esteban, the only person who actually fought in the revolution. For him, "Insomnia is like another person lying beside you...It is yourself, keeping you company...” (39).

Spatially, Esteban and the men live in darkness. They are like the ghostlike ship, the Urus, stuck in a liminal space whose crew is at once there and not there. Their absentpresence is like a ghost alluding to a Central American experience where one is seen but not recognized. As such, the men are like projected specters, homogenized and constituted by their absence — the fact that they are not "Americans" but foreigners who come from a location in crisis. To cope, the men re-invent their ghostly past through the optimism that one day the men will be able to repair the ship and their situation. But the past haunts them like a ghost that flickers within the dark rat-infested honk of metal 
rusting in the Brooklyn port. The "American" dream becomes a specter that never materializes, "all that grateful mierda about good luck just a desperate hoax” (21). Because the men have no money to go home and no way of legally entering the U.S., the men, invisible and forgotten, must exist in the hyphen between two "imagined communities:” America and Central America.

The crew not only lives in the cracks of spatial boundaries, but in-between time zones, and in the gaps of history, a kind of historical silencing, which Esteban and the crew's dreams and stories spatialize. One way this spatialization is represented in the novel is through the symbol of a Mickey Mouse wristwatch Esteban keeps in "the most intact sock which he has sacrificed to the wristwatch he keeps hidden inside...the only working watch or clock on board... which he's never even adjusted for the time zone passed (37). The watch was given to him by la Marta, the woman who he loved and who was involved in the BLI Sandinista coupe. The watch represents an internalized fetishism that measures time physically represented in the body of the watch, the "watch he keeps hidden inside” (37). The watch is an incorporated history of a revolutionary time as evidenced by the allusion of war that immediately follows the quote above:

Sometimes Esteban hears brief crackles of gunfire in the distance, thinks of ambushes that are over in the time it takes a column of bodies to fall down, in the time it takes for a column of troop-jammed trucks to turn into an immobile wall of torn and twisted steel, smoke, blood and screams (38).

Thrust into Esteban's consciousness is his role in the revolution. The gunfire emanating from los proyetos awakens a revolutionary experience that structures the way he sees. 
These are not just dreams; they are spatial/temporal ways of seeing that are often part of Central American experiences.

Central American spatialized ways of seeing challenge traditional conceptions of time and space and allow the reader to take note of the spatial-temporal dimension of Being. As the narrative suggests, "no one is quite the same person he was...not on the outside, certainly not on the inside: time fills them like the stagnant air in a flourishing mushroom cellar” (38). How the confined space of the ship changes the way the men see themselves is representative of a repressed time and concealed space at the same time visible and invisible.

The temporal/spatial distancing that is allegorized in the novel also mirrors the relationship between the novel and its readers. To the reader the characters are both there and not there. They are spatialized as characters of a text (characters as both alphabetical symbols and symbols that refer to flesh and blood human beings) contained, like the Urus contains the crew, in the confines of the book's borders. Like the walls of the ship, the book’s covers, simultaneously reveals and suppresses Being. As Heidegger suggests, there is always a lack, the unspoken silence of the gaps that will never be visible. The sensory experience of living in a state of limbo as described in the novel and the experience of reading, as such, expose significant epistemological and ontological notions of Being.

Take, for example, the idea of space and time. A traditional notion of space suggests a place, a concrete and tangible presence that is fixed and immobile. For instance, Central America is a place, a geographical location demarcated by borders, while time is something mobile, always moving forward, as in the saying "time never 
stops." However, close inspection reveals that the "Central American” border-crossings create ways of seeing that embody an absent-presence or a temporal-spatial embodiment that constructs subjectivity. Central America is both present and absent, the past as present:

The present of presence is not in time, it is ahead of time, in front of time. Or it is within it, not in its course, but in its most intimate heart or hollow. It is pure time subtracted from temporality: the space in which pure time opens out and in exposes itself. Space does not represent time, like a line that would be the immobile figure of a mobile process, but space opens time, distends time, distending the very moment to expose this present that does not pass, and that is time itself, negativity imposed for itself. Space is thus the origin of time. It is simultaneously its point of nullity and the whole extension of its successivity. It is the opening of time, the simultaneity of its spacing (Nancy Technique of the Present sec 1).

The liminal state the crew lives under as well as the recognition of their subjectivity as something contingent and constructed points to the fact that they live in a state of inbetweeness where space and time overlap. This doubling of space as time and time as space reveals Being in its most fundamental form.

However, there is a danger in even defining Central America as such. Always at stake is the means by which to approach the Central American immigrant experience and how this could possibly be represented. How can a reader, necessarily fenced off from this experience, approach a novel that disrupts singular readings? Because of the heterogeneity of Central America and the temporal-spatial event of border-crossings that 
simultaneously opens and conceals Being, the reading experience of the novel pushes for a re-imagining of Central America as a mysterious, forgotten, and imagined ship that is both "there" and not "there."

The novel is also an extension of the boom period because it enters the combat zone in that it contests fixed notions of "seeing" and the ways in which memory attributes value to places that are no longer "there” or "here.” The extension, as such, involves not only a temporal intertextuality between post-revolutionary texts like Goldman's in conversation with the boom period, it also involves a temporal/spatial extension. The convergence of space and time exposes Central American ways of seeing as colored by the "self's" relationship to bodies in place and place in relationship to space—as in geographical locations that denotes a position in time and space in relation to a past time and a past place.

The ordinary seamen as bodily subjects "necessarily have a relationship with the places that surround [them]...[places] define and structure [their sense of self, such that being dis-placed has a dramatic consequence on [their] experience of who they are, and even leaves them with a feeling of being homeless in the world” (Trigg 1). However, I am not suggesting that the place called Central America is a desirable destination for the crew. Unlike other US "Latino/a” American novels that thematize the desire to return "home,” The Ordinary Seaman hardly portrays "home” as a nostalgic place where the men desire to return, perhaps because "home" is in crisis. These conceptual knots that tint Central American ways of seeing need to be loosened "through several different angles. As some of the knots prove permanently bound, so our task will be to redirect the emphasis” of reading Central America as a homogenous space in crisis (Trigg 3). Indeed, 
in the novel the desire to define and pinpoint the men's origin is frustrated by the heterogeneity of their stories in spite of the fact that they are "in the same boat."

The characters imagine personhood as constructed through relationships among bodies, imagined communities, and the sharing of stories that express how bodies in space and time experience their temporal/spatial horizons. The men "do not live inside a void that could be colored with diverse shades of light, [they] live inside a set of relations that delineates sites which are irreducible to one another and absolutely not superimposable on one another" (Foucault 23). Despite the construction of nationhood or "home," the idea of returning home threatens to define and thereby fix and conceal personhood and individual bodies that desire to move beyond their confinements. The dream of returning to a "home" reveals a heterotopia in crisis viewed through the utopian mirror of revolucion that is shattered through a collection of stories. The novel as such is a collection of stories that disrupt the privileging of monolithic and objective history (the past as an object) by placing emphasis on pluralistic personal and intrapersonal subjective experiences.

Central American ways of seeing are uncontainable even when physically contained in a ship like the Urus. In allegorizing temporal/spatial experiences that are revealed as imagined subjectivities, as ironic as it might seem, the novel touches on the particularity of a Central American diaspora—-the heterogeneous Central American ways of seeing as singular-plural in the Nancian sense. While Central American immigrants often share the experience (literal or metaphorical) of border crossing, a revolutionary past, and a present that clouds their presence in the US "Latino/a" "community," they 
resists binary oppositions that attempt to see "Central Americans" as revolutionaries/antirevolutionaries, legal/illegal or any such dualistic notions.

Dualistic ways of seeing are deconstructed in the novel in an intriguing way. For instance, readers often take for granted that the central characters, Esteban, and his foil, el viejo, disappear at the end of the novel. It is no coincidence that these two characters are presented as stereotypical Nicaraguans. For example, for his role in the revolution, Esteban is often referred to as el piri, a derogatory term that loosely translates to "the communist.” Bernardo is el viejo, who pushes Esteban to start a new life and is symbolic of a time before the revolution in which Bernardo enjoyed the notoriety of being a waiter in a ship of high-ranking officers as well as a chauffeur to wealthy well-to-do families. Esteban and Bernardo can be read as representing distinct, but not diametrically opposed, temporal horizons in dialectic relationship with each other.

Esteban might be said to indicate a post-revolutionary imagining while el viejo arguably represents a pre-revolutionary one. However, one thing that they both share is that their identities are constructed based on their temporal/spatial positioning to the event—revolución. Juxtaposing these two temporally distinct characters with the heterogeneous life stories of the rest of the crew, discloses differences that are hidden beneath the stigma associated with the Central American crisis. As Mauricio Solaùm notes in U.S. Intervention and Regime Change in Nicaragua, this stigma is noted by the fact that the revolutionary event caused neighboring countries like Costa Rica, Mexico, and the US to guard their borders from the threat of communism and the people associated with the war infested regions. 
To dislocate this fixed spatial/temporal encasement that often colors the way Nicaraguans, Hondurans, Salvadorians, and Guatemalans are viewed within and outside the isthmus, the novel uses Bernardo and Esteban as symbolic embodiments of pre and post-revolutionary ways of seeing. It could be inferred that Esteban and Bernardo are at first the representatives of the entire crew's Central American identity. That they disappear at the end and only the other members of the crew are left, forces the reader to see beyond the constructed duality of a pre and post-revolutionary Central America. That is, at first the novel speaks of the crew through the lens of Bernardo and Esteban and as such they are like los letrados of the boom period. These symbols, however, disappear at the end and the reader is left unable to define the crew's identity.

The novel also indirectly speaks to the Central American boom period through the communion that the crew builds in the ship. This communion mimics the collectivity created through the revolutionary experience of the boom period. Although it is easier to link Bernardo and Esteban to los letrados, in a sense all the crew can be read as los letrados, which literately translates to men of letters. Are not the men in the ship literately letters who tell their stories through letters on a page? The characters as men of letters made up and conceived through letters speak in multiple ways. They are crafted symbols of Central American identities. In allowing the men to tell their stories, the reader is presented with the metaphor of identity as metaphor, identity as a construction through storytelling and the Central American identity as a collection of stories.

However, who is telling these stories? While los letrados of the boom period, whether with good or bad intention, attempted to speak for the people, post-revolutionary “Central American-American” texts, like The Ordinary Seamen, differ in that they do not 
seek to "speak for" or represent Central America. Instead, Goldman’s novel thematizes "speaking for" and "speaking as" through the narrative voice that confuses narrator and character and moves from first to third person as a means to play with the idea of representation. The novel's characters problematize speaking as an accurate form of representation in general. What I mean is that even if the subaltern speaks, s/he speaks through a language that, like Esteban, s/he does not own. Entering a language, as it has become a given by now, disseminates meaning and complicates representation.

The shifting narrative voice not only moves from third to first person, it also moves from English to Spanish, and from a narrator describing a character to the seamless merger of narrator moving from objective purveyor of facts and details that frame the novel-world to becoming a character-storyteller speaking as a character. For instance, when Esteban ventures out of the ship for the first time, a dialogue between Bernardo and Esteban ensues. "Where were you all night?” asks Bernardo. "I was here, but I couldn’t sleep. I went for a walk,” says Esteban. Next, the narrator describes Esteban's "perplexed affront” and the dialogue continues. However, all of a sudden there is no dialogue and Bernardo is either speaking or thinking, but there are neither italics nor quotations to suggest anything other than the fact that Bernardo is narrating to us. Here is an example:

The boy holds his eye a moment longer...Si pues that goes with Esteban, it's something he'd get into his head to do. Climb down and then back up...Why did he come back? [now back to dialogue] "You should leave" he persists. "The way Esmeralda did”... [back to no dialogue or italics] Does he want to end up like me? [Then back to dialogue] "She went from Nicaragua 
all the way to Israel.” [And now to no dialogue or italics] That Esmeralda has strayed so far (109)

Here, the third person omniscient narrator begins by describing the scene and Esteban's facial expression. Then, it switches to first-person and the narrative reads "si pues," a word that Bernardo repeatedly uses in the novel. Interestingly, Bernardo, like the narrator, becomes omniscient in this scene because he foresees Esteban's eventual escape from the ship when he says, "that goes with Esteban, it's something he would get into his head to do" (109). Even if this is no prediction, it is nevertheless a retrospective narrating that only one who is retelling an event could know. It is crucial that both the words $s i$ pues and Bernardo's prophetic words are not part of the dialogue nor are they italicized. The muddling of the narrative suggests that Bernardo is merged with the unknown omniscient narrative voice that repeatedly weaves in the characters' voices in this manner. It occurs when the other men tell their stories as well. Even Capitan Elias and Mark, the men who can be read as colonizers or as symbols of global capitalism dictating the lives of the crew, are woven into the narrative voice, which points to the intertextualtransnational complicated web of signification the novel portrays.

Besides complicating national identities, once Esteban escapes the ship and enters Brooklyn, the narrative is invested in representing the anxiety of remembering and forgetting and the possibility that Esteban, as symbolic subjectivity is no longer viable. The anxiety is thus associated with losing national identity in the contact zone, and in a sense the loss of personhood, if we consider how nations construct the imaginary self. When Esteban enters Brooklyn and meets Joaquina, an “illegal” Mexican manicurist, he is traumatized by the possibility that Joaquina will replace the memory of la Marta, his 
ex-girlfriend. And, it is the case that entering the "Latino" landscape in the US often means that Central Americans all of a sudden become Mexicans.

Therefore, la Marta is Nicaragua personified while Joaquina is the Mexican version of nationalism. La Marta is symbolic of la patria. In Italian, the word "Marta" means the lady. Marta is also the Spanish version of Martha, which refers to mother or motherland, and "in Christian allegory, [it is] used as a symbol or type of the active life...an active or busy woman, usually one occupied with domestic affairs" (OED "Martha” def 1). The lady, his lady, is killed during the revolution, but he does not want to forget her. Marta also contains the root word "Mar,” meaning ocean or sea. El Mar has traditionally been associated with women, but it also represents cross-currents, movement, mobility, and fluidity. Perhaps, Esteban desires a return to la patria. However, la Marta’s death can also be read as the death of movement and fluidity that is threatened by Joaquina's desire to define their relationship. As such, Joaquina's desire to make Esteban her boyfriend can also be read as a threat to Esteban's national identity. In this sense, the commitment to Joaquina that is solidified once Esteban disappears into the city represents a panethnicity, which I find a bit problematic.

As Martha Santangelo suggests, Central American narratives “dramatize[s] how panethnic “Latino”' alliances can occur out of structural similarities and great need in the urban centers of the U.S., such communities, in these authors' renderings, remain fragile and can be interrupted and even broken by the flaring of prior ways of imagining the self in relation to others" (Santangelo 174). Even as I agree that Central American-American novels often present the tension of the contact zone and provide a nuanced way of exploring the positive aspects of panethnicity, I find that Latinidad is nevertheless a term 
that conceals differences. Indeed, I read Esteban's disappearance as a negative aspect of Latinidad, one that reflects the US Latino literary studies underrepresentation and erasure of Central American-American narratives.

Close inspection, reveals that the novel alludes to displacement, erasure and the tension of remembering and forgetting from the outset. It begins with a short poem that reads:

Pass on, slow steamship, pass on, don’t stay...

Sail away from me, get out of my sight,

Get out from inside my heart,

Lose yourself in the distance

Oda Marítima by Fernando Pessoa (1)

Because of the stigma of revolución, the ease at which it is possible to disappear in the US Latino contact zones, and the desire to begin anew, this poem speaks nicely about the anxiety of "Central Americans.” Before the novel's six sections begin, it is telling that this poem is the novel's point of departure.

Furthermore, the opening section is called "Miracle," which is about the optimism of a new beginning. The novel ends with a section called "Scrap," which is about the ship that the men could not repair, but it is also about the revolutionary story repeating itself. To be clear, it is not that the last section of the novel concerns the revolution as such. Rather, it parallels the optimism of the Central American revolutionaries who believed in the utopian dream of a new beginning. However, at the end of the novel, the ship that becomes scrap metal and Esteban’s disappearance in the US “Latino” imaginary stunts the illusion of change. The men are forgotten and are deported, and Bernardo and Esteban 
disappear. Like the opening poem, I read the novel as being about the tension between remembering and forgetting and the disappearance of Central American subjectivities that are constructed to begin with and are erased in the contact zone.

In sum, like the Urus, the ship that is an allegory for the Central American isthmus, Central American identity is often constituted by a desire to return to a glorious past. For the ship, this past is one when it sailed freely across the sea. For Central America this past is one when it was the center of the world's attention, a place where revolución inspired and promised an escape from Western oppression. But a worthy scholarship of this region should be weary of being stuck in a revolución/non-revolución binary. Like the work of los letrados, this kind of naming is problematic. And, as I hope to show in the following chapter, the silencing of individual voices is not only a symptom of an identity being pushed from the outside, but also from years of self-imposed regional stratification and Spanish homogenization. As such what follows explores the specific case of Nicaragua, the place where the revolutionary moment is said to erupt, and a country often considered a space of racial and ethnic hybridity. Therefore, to probe deeper into the Central American question, we will now consider racial constructions in Nicaragua and how this is reflected in The Ordinary Seamen. 


\section{CHAPTER II: THE ORDINARY SEAMAN AND THE CASE OF NICARAGUA'S ATLANTIC COAST}

I came to the world anxious to uncover the meaning of things, my soul desirous to be at the origin of the world, and I am here an object among objects. Locked in this suffocating reification, I appealed to the Other so that his liberating gaze, gliding over my body suddenly smoothed of rough edges, would give me back the lightness of being I thought I had lost, and taking me out of the world put me back in the world. But just as I get to the other slope I stumble, and the Other fixes me in his gaze, his gesture and attitude, the same way you fix a preparation with a dye. I lose my temper, demand an explanation... Nothing doing. I explode. Here are the fragments put together by another me.

- Frantz Fanon, Black Skin, White Masks

Like racism, nationalism turned into something natural, as in a shared national origin, excludes, silences, and normalizes bodies into knowable units. To separate the two is quite difficult. The construction of a race is part of nation building where singularities are shattered and reassembled through exchanges between the colonizer and the colonized. However, both the colonizers and the colonized are able to erase differences. This is evident in the way Black experience is thought to be universal in spite of different cultural contexts that challenge its universality. Black identity is not constructed in a vacuum. The gaze of the Other separated, isolated from the gaze of the colonizer, says Fanon, also labels and places the "self "in a category of in or out. That is, even when a "black" community is segregated from the colonizer, this community necessarily creates the boundaries for itself. The black community, as such, also homogenizes differences. So it is that race, constructed from the fragments of the Other, is rehashed by someone other than the self. But there is a paradox here. The affirmation of a racial self, constructed as it may be, also causes a rupture that exposes the fabrication of the 
homogenous nation state. The case of Nicaragua's Afro-Caribbean coast is crucial to examine in this regard, even if by my pen I inevitably risk becoming a colonizer too. In the previous chapter, I suggested that Central America is a kind of nation because it defines people's identity in a similar way a nation does. And, that Central American nationalism is predicated on a forged mestizo identity crafted by the revolutionary letrados and the encasement of the four countries "in crisis" between Costa Rica and Belize: Nicaragua, Honduras, El Salvador, and Guatemala. The Chapter aimed at exploring the region at a macro level to demonstrate the constitutive nature of both the Central American literary boom period and the region's revolutionary past. From this point of departure, I suggested that Central American-American novels like The Ordinary Seamen are the outcome of the boom period, and that Central American ways of seeing are affected by temporal/spatial experiences, including immigration, remembering and forgetting, and assimilation in the contact zone. In short, I claimed that storytelling and the disappearance of the central characters, Esteban and Bernardo, at the end of the novel, point to a transnational perspective that is pluralistic. And, above all, I claimed that Central America is a kind of nation that is constructed both from within and from the outside, and that the term "Central America” silences histories and different ways of seeing that do not fit the accepted mold. In this chapter, I move away from the broader conception of the isthmus to zoom in and explore Nicaragua's Atlantic Coast in hopes of making visible the silenced and ignored Central American black Atlantic diaspora.

That neither Paul Gilroy's groundbreaking work, The Black Atlantic, nor prominent Caribbean scholar Antonio Benitez-Rojo's work The Repeating Island include Central America in their analysis makes the analysis of the novel alongside Nicaragua's 
Atlantic Coast that much more vital. But, how does this Caribbean segment of Central America contribute to Benitez-Rojo’s and Paul Gilroy’s scholarship? Can we take anything away from this “dark” and forgotten coast? Finally, how does this coast get represented in The Ordinary Seaman?

Because the little scholarship that has been produced about The Ordinary Seaman has looked at it as a US Latino/a novel, one of my most important interpretive moves is to read The Ordinary Seaman as a black Atlantic text. A closer reading of the text reveals significant black Atlantic elements that expand the familiar meaning of the term "blackness.” That the novel pushes for transnational and panethnic US Latino/a solidarity is undeniable, but the novel also reveals significant and varying black experiences that cannot be ignored. Unquestionably, The Ordinary Seaman articulates a different kind of black Atlantic condition. It hints toward racial hybridity, racial construction, and diasporic bodily expressions of music and dance that parallel Nicaragua's racial spaces, relations, and hidden blackness. The novel argues for, among other things, the viability of black internationalism, and it represents this blackness as part of an incorporated spatialized memory that has more to do with experience and spatial boundaries than it does with skin tone. By creating a link between different oppressed groups, regardless of race or ethnicity, the novel redefines “blackness” into something akin to Paul Gilroy’s black Atlantic where black experiences find "their commonality...by their reference to the central, irreducible sign of their common racial subordination” (Gilroy 86).

The novel, therefore, provides a fascinating vehicle to speak of black Caribbean and black Atlantic expressions. Any reading of a novel that deals with Central American cultural expressions must consider Nicaragua’s Caribbean and/or black Atlantic spaces. 
As Benitez-Rojo suggests, the Caribbean should be reread, a "reading in which every text begins to reveal its own textuality" as opposed to imposing one's reading on the Caribbean, or trying to fix the Caribbean experience (2). Benitez-Rojo encourages an approach that allows the Caribbean's fluctuating cultures to speak. He proposes that we start with "something concrete and easily demonstrated, a geographical fact: that the Antilles are an island bridge connecting, in 'another way,' North and South America” (2). However, he ignores Central America’s Caribbean coast. Besides the meta-archipelago, there is of course another bridge that connects north and south—-the Central American isthmus. Nevertheless, Benitez-Rojo suggests that somehow the Caribbean islands are uniquely positioned to speak about the "vast collisions of races and cultures" and of the “Caribbean machine” (Benitez-Rojo 3). In fact, he goes as far as saying:

If we were to take the Central American ligament as our connection between continents, the result would be much less fruitful...the connection [Central America] gains objective importance only on maps concerned with our current situation seen as geography, geopolitics, military strategy, and finance...these are maps we all know and carry within us...In my reading, the link that really counts is the one made by the Caribbean machine, whose flux, whose noise, whose presence covers the map of world history's contingencies, through the great changes in economic discourse...through the vast collisions of races and cultures that humankind has seen (2-3)

That Benitez-Rojo suggests that the Central American ligament is a map "we all know and carry within us” contradicts the experience of Central American scholars like Arturo 
Arias, Ana Patricia Rodriquez and others. Central America's race relations have something new to offer to black Atlantic Caribbean scholarship. Despite Benitez-Rojo’s attempt to stake a claim for the Caribbean islands as central to the discourse of postindustrial society's racial collisions and cultural configurations, the Caribbean machine and the idea of an imaginative island bridge that connects north and south needs to take in to consideration the material land bridge of the isthmusain countries which are imaginatively divided and turned into separate yet repeating islands in their own right.

As Ana Patricia Rodriquez explains in Dividing the Isthmus, Central America is a relatively unknown and ignored floating land bridge that connects north and south. Rodriguez points to her Central American literature class that she teaches to reveal the extent to which the isthmus is underrepresented in the American education system. She tells of her first day quiz where she hands out cutout pieces of the Central American countries. She then asks her students to construct a map of the isthmus and she finds that: often Belize and Panama fall off the map, Guatemala topples over a ragged strip of land, El Salvador acquires an Atlantic coast, Honduras borders Mexico, Nicaragua becomes an undistinguishable green expanse, and Costa Rica does not quite fit in with the others...Central America as a whole lies suspended somewhere between amorphous masses on the north and south and east and west. As if it were an island, Central America appears without physical, geographical, and historical ties to the rest of the western hemisphere and the world...[Rodriquez ponders] why, for many people, Central America figures as an unknown, nebulous zone. (2) 
Rodriguez's research suggests that "in a certain way," to use Benitez-Rojo's term, the isthmus offers a different reading of the Caribbean. Rather than a bridge imaginatively connecting the northern and southern hemispheres, Central America is a physically present, and yet, invisible bridge that is imaginatively represented as fixed and singular. However, despite the visual unity that is represented on maps, the reality is that Central America is fragmented, fluid and unstable; it is not a place "we all know and carry within us” (Benitez-Rojo 3). In fact, rather than "knowing it," it occupies a ghostlike presence and is an uncomfortable eyesore in the neat scholarly discourse of cultural and racial processes in progress.

If for Benitez-Rojo Central America falls outside of his scope of interests because it does not fit well with his Caribbean emphasis, for Paul Gilroy Central America does not appear as part of the black Atlantic. While Gilroy suggests that blackness can be any color other than white and his theory of the commonality of the black experience is explored via the US, Caribbean, African, and British connection, Gilroy does not explore the Central American Caribbean, and in particular Nicaragua's Atlantic coast. His main claim is that what matters to him is "the structure of feeling, producing, communicating, and remembering," which he calls "the black Atlantic” (3). He contends that music is the link connecting the black Atlantic, and claims that black music is defined by its commitment to expressing solidarity, angst, and alternative futures. Black music, according to Gilroy, "in developing black struggles by communicating information, organizing consciousness, and testing out or deploying forms of subjectivity...poses the world as it is against the world as the racially subordinated would like it to be” (36). I will shortly return to this idea during my analysis of The Ordinary Seaman. It is most 
imperative, however, to first provide an ideological, historical and cultural base for this analysis.

Besides the pervasive idea of a homogenous region in crisis and the site of revolutionary wars that I suggest forms a false national identity that entraps and silences people, prevalent among non-academics and academics alike is the concept of a Central American mestizaje where Europeans, indigenous groups and Africans mixed to create a "brown” race. In Central America, mestizaje earns its signifying force from ancestral Mayan culture. Scholars like Gloria Anazulda and other Mexican activist writers and even Central Americanist Arturo Arias have, on occasion, strategically used "mestizaje" as a subversive term that forms solidarity in the isthmus. The idea that Central Americans are mestizos creates a kind of pride that is supposed to challenge the idea of fixed racial categories. However, this term has also become highly romanticized as evidenced by the Central American revolutionary cultural movement of the 80s and the nation-building project discussed in the previous chapter. As Gilroy suggests, scholarly and political commentators have too often "fallen back on the idea of cultural nationalism" (3). To speak of the black Atlantic, we need to consider "creolization, metissage, mestizaje, and hybridity...” (Gilroy 3). Gilroy goes beyond cultural nationalism and the idea, for example, that prior to the arrival of black people to Britain, their existed a natural, stable, and undifferentiated British culture (7). In the same vein, I want to deconstruct the idea that prior to Central American "mestizaje" and the arrival of African and Europeans to the isthmus racial identities were pure and stable.

Although Central American "mestizaje," is helpful as a way to view how race is constructed, it is dismissive of a large segment of "Creoles"—black and Miskito people, 
from the Nicaraguan Atlantic coast. Furthermore, it obscures the fact that the Pacific segment of Nicaragua contains hidden blackness that gets washed away by the idea of mestizo nationalism. According to Juliet Hooker, prior to Nicaragua’s 1987 multicultural citizen reform, it had been widely accepted that Nicaragua's national identity was mestizo. By mestizo, the ideologues suggested that Nicaraguans should be proud that they were “Indios,” Indios who did not let their cultural roots be stripped away by European colonizers. They suggested that "el Indio" turned the Spaniard who stayed in the country into Indio instead of the other way around. The "pure” Indio ideology led to the construction of other narratives that suggested that Nicaraguans are guerilleros who will not be ruled. Nicaraguan pride, la patria, and national "mestizaje” was the product of long held ideologies pushed by various governments and revolutionaries who used "mestizaje" to their advantage as a means to achieve their political goals.

Hooker points out that mestizo nationalism was used to colonize Nicaragua's Atlantic coast. He explains, "Ideologies of mestizaje legitimated the Nicaraguan state's efforts to colonize the country's outlying regions and questioned the right to full citizenship of the black and indigenous inhabitants of these areas” (15). Mestizaje discourse stripped los Costeños (people from the Atlantic coast) of the idea of the nation altogether through denied citizenship. The Sandinistas, it appeared, saw this inequality and passed the 1987 reform that gave the Miskito and Black inhabitants of the Atlantic coast full citizenship and constitutional protection. While Nicaragua was the first country in Latin America to pass such a law, which led to similar reforms across Central America, what was supposed to be a "radical revision of the central tenets of dominant nationalist discourses,” was never actually put into practice (Hooker 15). 
Notwithstanding the idea of a multicultural Nicaragua that was supposedly enacted by the 1987 reform, Hooker argues that los Costeños continue to endure the same discrimination and are still not part of the accepted Nicaraguan national identity. Hooker suggests that while governments had dominance of the entire geographical region that is Nicaragua, the coast was largely ignored when it came to policies that would improve the wellbeing of the nation's citizens. Any worthwhile policy that helped the citizens of Nicaragua was reserved for the "mestizos" of the Pacific region.

In fact, to this day, even as the country's infrastructure has improved there is no road, bridge or any path that connects the Pacific inhabitants to the Costeños. To reach the Atlantic coast one must take a full day boat ride or fly a small plane over the dense forest and mountainous region that separates the Atlantic coast from the "mestizo" inhabitants of the Pacific. Ideological wars ensued because of each passing government's lack of concern for the Atlantic coast. The ruling government's lack of concern for the Atlantic has created a separatist sentiment in los Costeños.

In "Splitting the Country: The Case of the Atlantic Coast of Nicaragua," Luis Sanchez explains that the Atlantic coast consists of two autonomous regions, the Atlantic North and the Atlantic South. Each region has its own government even though in the grand scheme of things los Costeños are still under Nicaraguan rule and are part of the national budget. The right to self-govern, explains Sanchez, is the direct result of the 1987 Sandinista reform and the National Assembly approved "Ley de Autonomía, which created the North Atlantic Autonomous Region, and the South Atlantic Autonomous Region... [granting] some home rule for the different ethnic communities inhabiting the Atlantic Coast” (11). Similar to the north and south separatist sentiment the US suffered 
during slavery and the civil rights movement, Nicaragua continues to harbor racial, economic, and political conflicts between east and west. US intervention, always a problem in the region, took advantage of this animosity during the Reagan administration, and used los Costeños to fight against the Sandinista government of the 1980s. As Sanchez explains:

In the mid-1980s, President Reagan authorized $\$ 100$ million in military and non-military support for groups trying to overthrow the Sandinista government, arguing that they were threatening US security in the region. The ethnic minorities of the Atlantic Coast joined the counterrevolutionary war against the Sandinista government. As a way to find a peaceful solution the revolutionary government agreed to a negotiated cease-fire with the leaders of the Atlantic Coast. Those negotiations resulted in...the right of the indigenous people to self-government (11)

Sanchez argues that the two autonomous regions of the Atlantic Coast express a desire for partition, but the local leaders have not convinced the population that it would be feasible to part without detrimental consequences to the region. It would be difficult indeed, given the Atlantic coast's economic subordination to the supposed mestizo western region, a subordination that parallels that of US intervention. For all intended purposes and interests, the Pacific ruling class—a paradoxical term given the regions civil wars and the Sandinistas' armed struggle over the people's rights—is mimicking the imperialism and colonization from which it sought to free itself. While it seems that governments old and new have set up laws to help the Atlantic coast, what these governments are doing is creating the conditions to maintain power while giving los 
Costeños the false impression that autonomy means self-governance. And, of course, this is what the US has done to Nicaragua as a whole and to Latin America in general.

The separatist sentiment and the literal geographical separation of these regions have led some to resist the fact that "blackness" is infused within the "mestizo" Pacific regions. It is a widely held myth that Afro-Caribbean people never mingled and crossed over. "Colonized by Britain and geographically isolated from the Spanish traditions of the majority sector, they remain both remote and distinct. No highway links the east coast to the west...[los Costeños] saw the revolution as a Spanish thing” (Lancaster 341). There is an undeniable separatist sentiment between east and west. Lancaster points out that despite the Sandinista government's acknowledgement that a race problem exists, and its attempt to remedy it, people who claim not to be racist and speak of a progressive agenda see the Atlantic coast as utterly Other. For example:

Elvis, a member of the Sandinista Youth organization....and a Marxist trained in materialism...took it as a matter of personal pride that he was not superstitious. [when asked of] various tours of military duty in the mountainous...He spoke about hunger, isolation, boredom, and danger. "We were in the rain a lot. There were almost no provisions...It was especially bad, having to eat monkeys, because when you skin them, they look like men... But the worst was when they sent me to the Atlantic Coast...there are a lot of evil people (gente mala) on the Coast.” [The interview wonders] if he meant counterrevolutionaries, but gente mala was not a political designation: "Look, I was never sick in the mountains. But on the Atlantic Coast, I got a fungus, a skin disease...” [Interviewer]: But 
what's that got to do with bad people?...Elvis clarified, "because they all practice witchcraft. A negra (black woman) from Bluefields was looking at me, very strange, for a long time, and a couple of days later, I got sick”...I know she caused it”... [Interviewer] “I didn't think you believed in witches.” "Of course not!” Elvis replied. "Not here. But the Atlantic Coast; that's a different thing” (Lancaster 340).

The ideology at work is that the people from the Atlantic Coast are evil because they use witchcraft. According to Elvis’ account, los Costeños are mysterious and dangerous because they are different. It is not hard to see how the idea of separate and racially distinct regions has persisted for so long. The Pacific is thought to house only mestizos of indigenous and Spanish ancestry, and the Atlantic coast is said to contain "pure" black and Miskito inhabitants. However, evidence suggests that "blackness" extends, as far in land as Granada, Nicaragua where Spanish Colonial architecture litters the landscape, and where no "black" people are said to exist.

Inversely, even though it is true that there exists an ideological and physical separation between the Pacific and Atlantic sectors, it is not true that los Costeños see themselves, universally, as blacks or as Afro-Caribbean. Case studies including that of Edmund T. Gordon and Mark Anderson suggest that people of the Atlantic region have competing identity markers. In a visit to Bluefields, Nicaragua, Gordon was shocked to see that many did not see themselves as black, despite their skin color. Gordon and Anderson point to an example of a local who explains his cultural roots: "We call ourselves Creole” says the man, "and people say if you are Black you come from Africa. But we are Creoles, a very mixed group. Many of us...our ancestors, we don't find them 
in Africa...many of our people on the North are Jamaicans...we don't have any pure Black people here in Bluefields” (283). Interestingly, Costeños often do not claim black ancestry even when their skin color might suggests to an outsider that they are "black." Although this demonstrates that the English colonized Nicaragua's Atlantic coast, it also points to how "blackness" is regionally contextualized.

Certainly, Gordon’s interviews of various people in Nicaragua’s Atlantic coast provide surprising answers to the ethno/racial question. For instance, one of the men interviewed identified with a monarchy:

[We] had a king...The king was Miskito. Miskito people. Originally, I say, from England...[Gordon: Who was from England?] Both the Indians and the Creoles. Both of them...[Gordon: So the Miskito and the Creoles came from England to here?] That's right. [Gordon: So then they came from England to what, to Jamaica and Cayman and then from there to here?] Exactly, because...those poor people that died [previous generations of Creoles]. They still believed that here supposed to be for England (283) Yet another person telling of the oral history of his ancestors claims Cayman heritage and English origins: "we descend from people from Caymans and from Providence...trace you right back to Scotland and Englishman...The Englishman was like me...that is what they taught me, that I was descended from Englishmen” (283). The mixed answers provided by various people points to a hybrid, heterogeneous region that contests the traditional conceptions of "blackness." The Atlantic coast points to a different kind of black Atlantic that neither Paul Gilroy nor Benitez-Rojo consider. For example, they have not considered that having black skin does not necessarily mean that one identifies with 
an African Diaspora. Yet, that is not to say that there are no people who identify as "black" in the traditional sense. Indeed, Gordon, Anderson, and others suggest that there is in fact a large segment of the Atlantic population that identify with black Americans. Nevertheless, the variety of cultural and racial self-fashioning occurring in Nicaragua suggests that to be black means many different things to many different people.

Other studies like that conducted by Gail McGarrity suggest that "artificial and irrational distinction...both in political and academic circles, have been asserted between a predominantly ‘black or African descended Caribbean’ and a 'predominantly mestizo’ / 'white' or Spanish Latin America” (46). To demonstrate the fabricated distinction between the "black" Caribbean and Spanish "mestizo" Latin America, McGarrity examines Nicaragua's race relations and finds that mestizaje stemming from notions of racial purity have concealed "blackness" in the Pacific region of Nicaragua. It has led to what McGarrity calls "the myth of the iron curtain.” In calling it a myth, McGarrity does not claim that separatist sentiments do not exist, but rather, McGarrity suggests that the myth is the idea that separate and racially pure races exist in the eastern and western poles. The powerful myth that "pure" and "separate" races exist, she argues, is the cause of racial and political tension in Nicaragua.

McGarrity's work indicates a highly assorted cultural mystification where blackness is kept at bay. For example, McGarrity points to the traditional national instrument, la marimba, which is said to embody the Indio/mestizo spirit, and finds that the instrument is actually of African origin. She also examines the famous Costeño dance, el Palo de mayo, and the tradition of carnival surrounding it. This musical symbol of black Atlantic identity, finds McGarrity, is actually of Dutch origin (Maypole dance). 
In other words, the mestizo sector contains African infusions and the Afro-Caribbean coast is infused with indigenous and European lineage.

In the Atlantic coast there are blacks and white Creoles mixed in with Miskito groups, such as Sumo, Rama, Tawira, and mixtures thereof, all of which are considered "los negros" by those in the Pacific. Yet, despite the ideology of pure "indio" national identity, traces of African ancestry are found in the most remote and supposedly purely mestizo regions of the country. In the end, the point that McGarrity's research makes is that the black/mestizo separation is false, which explains, as she points out, why some of the photography of la contra and los Sandinistas on their way to battle, figure black, white, and mulato faces as well as dark "Indios” with afros. In Nicaragua, "mestizos” and "blacks" take on various shades of meaning that are dismantled when the curtain between east and west is lifted.

Black Atlantic and Caribbean scholarship, however, have largely overlooked the vast array of expressions and movements, black or otherwise, that exude from Central America. Perhaps because "Black Culture, the Black Movement...Blackness itself, has been published...within a particular social and political context, expressions of blackness from outside [“the black Atlantic”] world have unavoidably been marginalized” (McGarrity 59). Instead of resisting the fact that Nicaragua's Atlantic coast pokes holes in traditional black Atlantic representations, further work should be amassed, work that reveals other ways of seeing that "reveal [their] own textuality” (Benitez-Rojo 2).

Correspondingly, a novel concerning Central American ways of seeing should include black Atlantic elements. The Ordinary Seaman definitely contains such expressions. Far from being ordinary, the ordinary seamen present a complex 
arrangement of identity markers, which are brought into contact with other identities in the Brooklyn harbor. As mentioned earlier, Goldman's novel can be read as a black Atlantic text that expands our conception of "blackness." In creating a space where racial and ethnic categories are blurred, the novel links the crew's experience of oppression to that of "los blacks" from "los proyectos" because both groups share a common Western oppressor. Concentrating on the distinction between categories of race and ethnicity takes focus away from the fact that the majority of people who are underprivileged are those who are considered or see themselves as "black," "Latino/a," “Central American,” “Nicaraguan,” "Costeño,” and so on.

Just as black means many things in Nicaragua, in the novel, "los blacks" are not only comprised of people who are “African Americans.” Los proyectos are described as "a whole noisy barrio happening in doors: the night air like a sizzling frying pan full of all kinds of music mixed together, merengue, salsa, rap, reggae...” (53). As the narrative describes it, los proyectos encloses a mixture of black experiences that include Dominicans, Puerto Ricans and Cubans, which can also, but not necessarily, be part of the Afro-Caribbean.

That the novel mentions these "Latino" groups within the context of los proyectos and later mentions these groups within a "Latino" context suggests that "blackness" is contextually and spatially constructed in homogenizing ways. For example, the reader observes how race is contextualized when Esteban decides to leave the ship and look for refuge in a Latin American cafeteria. The streets of the "Latino" neighborhood are said to contain "lots of men, many mestizos...” (209). Conversely, in los proyectos various Latin American nationalities, like Dominicans and Cubans, are all labeled as "los blacks," not 
mixed or hybrid but as the same. Whether a person is from Cuba, speaks Spanish or has a mixed background (and there is no such thing as a pure race of course), if a person resides in los proyectos, he or she is black.

Inside los proyectos los blacks are exotic and dangerous. In the "Latino” cafeteria, on the other hand, the interpretation of skin color is muddled and takes on a different significance. Skin color loses its significance; language, immigration, and nationality carry more weight. That the cafeteria is a space of a shared language and a similar immigration experience makes the cafeteria a place of safety where color lines are blurred. Rather than dark skin obtaining a negative connotation, it becomes beautiful. For example, the Dominican waitress in the cafeteria does not have black skin, but "chocolate skin.” The waitress is described as "a dark-skinned mulata with...liquid eyes, coarsely straight, reddish hair...[with pretty] chocolate skin” (240-41). Even though it seems that the ordinary seamen fear "los blacks" because of their skin color, closer inspection uncovers the way space constitutes the identity that is projected onto "los blacks."

The projection of danger and evil is constituted by spatial boundaries and the myth of an exotic and dangerous place. That skin color is spatially contextualized is made clearer when Esteban sees the description of a lost black cat named "Dolores" on a flyer projected on a windowpane. Within the "Latino" context of a Cuban beauty salon in Brooklyn, Dolores, the "black" cat, loses its "blackness.” For example, "Here is the rare thing: the cat's color is listed as 'aceituna'” says Esteban, "but olives can be black or green. If black olive, why list the cat's color as olive and not black? And who ever heard of an olive green cat?” (209). When Joaquina explains that perhaps Gonzalo, the Cuban hairstylist who posted the flyer, is colorblind, Esteban doubts it, wondering "How can the 
cat be olive colored?...Gonzalo thinks its olive green...Maybe he’s colorblind. But imagine. You think women would get their hair dyed if they thought he was colorblind ?” (212). It is not that Gonzalo is colorblind. The black cat projected on the windowpane is meant to emphasize how spatial boundaries contextualize and construct racial markers. The projected photograph of a black cat re-presented within a "Latino" context discloses how "blackness" acquires different shades of meaning in different places and spaces. Instance like the ones above pair up well with the research McGarrity and others have conducted about the Pacific and Atlantic regions of Nicaragua. Indeed, the novel alludes to the myth of the iron curtain, which McGarrity's work deconstructs. The iron curtain myth is alluded to in the metaphor of metal and steal, the ship Urus, which creates an iron curtain separating the crew from the unknown-yet projected upon, project housing buildings of Brooklyn. Despite this alleged racial separation, the supposedly allmestizo crew also includes "Bonnie Mackenzie, the one moreno in the crew, a cherubic costeño from Puerto Cortés” who is characterized by his skin color and is nicknamed "el buzo,” a deep-sea diver, because his skin is as dark as a wetsuit (15). Not only is Bonnie black and thus like "los blacks" of los proyectos, he is also expected to speak English given his name and the fact that he is Costeño, a primarily English speaking area. Ironically, however, besides knowing the lyrics to a Bob Marley song, which he recites but does not understand, he cannot speak English. Because he does not fit neatly in any category (Central American, Costeño, or Black), Bonnie problematizes fixed and easy notions of race and their constructed spatial designations.

Even though he receives little attention in the novel, his nickname, "El buzo" is telling because it suggests that like the depth of the ocean explored by a deep-sea diver, 
the fabricated narrative of Central American mestizaje drowns "blackness” away. "El Buzo" is there among the crew's mix, but it is as if the men do not see his blackness. For the crew, black people exist on the other side, in los proyectos: "los blacks all came from los proyectos, they imagined” (52). They “project” blackness onto a "noisy group of teenaged morenos [that] came late at night to sit at the end to the pier, under the Urus's prow. Los Blacks was what Capitan Elias called them, and soon most of the crew began calling them that too" (45). Only after the crew wants to resolve the fact that "los blacks" are constantly throwing beer bottles at their ship do they become aware of Bonnies possible connection to “los Blacks:” “ ‘Why don’t we just send El Buzo down to talk to them?' said El Barbie. 'He’s a mandingo'” (51).

"Mandingo" refers to "A member of a distinctive ethnic and cultural group of West Africa speaking closely related dialects of the largest language” (OED def 1). This means that the crew believes that somehow el Buzo would be able to communicate with los blacks. However, the only English Bonnie knows are the lyrics to a Bob Marley song. The indication that "el buzo" should speak English because his name is Bonnie Mackenzie and he comes from the Atlantic Coast, a region where the majority speaks English, is turned into a humorous moment. As such, el Buzo deconstructs stable definitions of Blackness both within the Atlantic Coast, and in general.

In many ways the novel reveals the anxiety of race relations in Nicaragua. For example, the people from los proyectos mirror the people from the Atlantic Coast in that for the crew they are a mysterious and dangerous people. At this point in the novel, the crew is running out of rations and need to find food outside the ship, but the crew is fearstruck and do not leave the ship even though they are literally dying to go into Brooklyn. 
"When los blacks were on the pier the crew avoided standing by the rail and spoke...in near whisper...The ladder was always up” (47). Like the story of Elvis, the young Sandinista I presented earlier, many of the men had experienced horrible conditions in Central America. Esteban, for example, fought in the mountains of Nicaragua against la contra, yet he is afraid to cross into lo proyectos.

That the men do not want to be seen by los blacks can be read in various ways. While reading the scene as an allusion to the dark experience of being illegal and invisible in the United States is the traditional way most scholars interpret this scene, I read the close encounter with los blacks as the crew not wanting to mingle and be seen by "los blacks," the evil and mysterious people from los proyectos. Just like Elvis tells in Gordon's case study, arguably this scene alludes to the stories of young Sandinistas who would venture into the Atlantic Coast and report supernatural, evil experiences, the evil eye of "la negra" that causes illness and death. Indeed, for the crew, "Los blacks all came from los proyectos” (52). The narrative describes los proyectos as a dangerous and forbidden place, and the crew expresses fear of leaving the ship because of los blacks. But, what about Bonnie Mackenzie, isn’t he black? Why are the men not afraid of el Buzo? How do they figure him different from los blacks? I argue that Bonnie, like the olive-colored cat, Dolores, emphasizes the way space constitutes identity.

While spatial boundaries seem to segregate the crew and los blacks, the novel eventually makes symbolic links between the crew and los blacks when los blacks discover the crew:

Now that they had been discovered los blacks grew more and more interested in the crew...someone took a turn shouting at them...'You 
fucked you fucked you po mothufucks fucked...Los blacks seemed to know something about the Urus; it was as if they'd somehow figured out what the crew's situation was. They spray-painted DEATH SHIP on the grain elevator....and another night someone wrote CAGUERO DE LA MUERTE, which means 'Shitter of death,' though they probably meant 'Cargo Ship of Death.' leaving out the $r$ in carguero (49-50)

Here, the narrative reduces the tension created by the fear of the Other by using humor. It also makes a linguistic connection between groups, suggesting that there are Spanishspeaking people among los blacks.

The narrative further makes a connection between the groups through metalinguistic expressions of music and dance:

Sometimes [los blacks] lost themselves in long, nearly serene dance parties, tracing rhythm burning away the pumping, angry vehemence of much of the music like sun a layer of mist. Most of the crew...watched. Spidery, beautiful, hypnotic...dances. Girls slowly rubbing their crotches to the music and letting everybody see, one arm extended and flapping, the boys taking on one powerful sexual, or magically robotic pose after another. They looked like bodies endlessly stepping out of their own bodies to become other bodies...bare limbs and shoulders against black water and night. Sunglasses in the dark (48)

Sunglasses in the dark do not let one see clearly. They turn everyone into black figures. The sunglasses, therefore, strip the significance of skin color off of every body. What is left are bodies dancing in the dark, hypnotizing the crew that imagines dancing along 
with the men and women below. It is either that the people dancing below are no longer "los blacks," or that the ordinary seamen also become "los blacks" because it is the crew who appear as dark shadows bobbing their black heads to the music in the distance.

In effect, music and dancing makes the crew lose their fear, but not enough to join them below. Nevertheless, the scene, much like the stories of sex and desire that the men tell, makes reference to Gilroy’s black Atlantic music. In the dance ritual of the novel, "Lines between self and other are blurred and special forms of pleasure are created as a result of the meetings and conversations that are established between one racial self and others” (79). Antiphony, a word repeated in Gilroy's text, suggests a musical exchange, contestation, and call and response between groups that fits nicely with the idea that music arrives at "a certain kind" of truth that is incorporated in dance and rhythm. If we consider storytelling as a mode of chanting, a musical expression that links different experiences with the purpose of entertaining and bringing pleasure to the crew, than the novel is full of musical instances that move beyond static meaning. Stories become lyrical manifestations that express desire, pleasure, and transcend racial categories.

While one reading of the novel suggests that los proyectos is a mysterious space that parallels the Atlantic coast, the allusion to war and revolution evidenced by bottles hurled at the Urus, and the music boxes that are described as machine guns, suggests that the narrative wants the reader to see a reversal of roles as well. "When los blacks left the pier at night, walking off with music boxes carried on their shoulders like high-caliber machine guns, they liked to stop and hurl empty beer bottles” (45-46). In this scene the crew is experiencing what it feels like to live in the Atlantic coast. Placing the crew in the Atlantic implies that the crew, like los blacks, is living a kind of black experience. 
Indeed, the Urus is often described as a dark ghostly ship. Allusions to ghosts, and even a chapter called "Disastrous" that features a black cat that constantly follows the crew associates the Urus with superstitious descriptions of Nicaragua's Atlantic coast. All of this suggests the shifting, contextual meanings of "Blackness."

The narrative takes the role reversal a step further through the following imagery: “The afternoon's blazing sun and heat languished in the mess and cabins like an invisible fever patient, so they ate dinner outside...most of them shirtless and barefoot, oblivious to mosquitoes” (46). Here, the ordinary seamen live in conditions similar to descriptions in Roger Lancaster's study. As Lancaster points out, Spanish colonizers trying to traverse the dense forests of the Atlantic coast described it as intolerable because of the excess of mosquitos. They also report that the natives were oblivious to the mosquitos, just like the Urus' crew. The novel presents many layers of oppression with the ordinary seamen taking on various subject positions expressed through metaphor and the crew's experiences.

Placing the ordinary seamen in a similar setting is an obvious allusion to Nicaragua's Atlantic coast. In fact, the Urus is physically in the Atlantic as the ship is docked in Brooklyn. As if that isn't enough, to drive the point home, the narrative literately transforms the crew into black men. It depicts the crew slowly becoming darker until "it was as if their skins were becoming unwashably filmed over. By late summer, they were no longer taken by surprise by the sight of one another...” (46). Their identities are erased, and “it seemed that to Esteban he didn't recognize anybody, had no idea who they all were. All those personalities that had already been tagged with nicknames seemed to flee into the night” (55). Their living conditions and deflated enthusiasm that 
comes after they realized that things would not improve creates a solidarity based on the shared experience of oppression.

Rather than read the crews encounter with los blacks as a clash of cultures that draw clear lines between the Spanish "mestizo" crew and the English-speaking black people from los proyectos, I read their encounter as one of the most central, yet overlooked scenes in the novel. A reading that only points to "Latino/a" issues and how new immigrants from Central America fit within the latino/a landscape has to contend with the fact that the crews cultural encounter in los proyectos suggests that The Ordinary Seaman also contains black Atlantic expressions. Of course, it is only once Esteban is able to cross the Brooklyn border where los blacks live that he enters the US "Latino/a" contact zone. Esteban is transformed by this experience and carries with him a certain type of blackness connected to a oppressor that transcends national identity. As such, any reading that ignores the issues of "blackness" I have presented in this chapter is missing one of the most important points of the novel—-that to be transnational also involves, in some sense, being transracial. It means to acknowledge the hidden blackness within Central America ways of seeing. 


\section{CLOSING}

When I was in the process of choosing a topic to write about, I knew that I would somehow incorporate identity politics within my thesis. Born in Costa Rica to Nicaraguan parents and raised in Miami, I always felt a bit confused about the identity markers being imposed on me. My parents would brag that I was “Tico” (nickname for Costa Rican) as if somehow that made me better. As a child my cousins and friends would make fun of me because I was not Nicaraguan, and once I began elementary school in Miami, I noticed that regardless of where I was born or how I was culturally raised, I simply was grouped into those kids, the ESOL kids, a group which came with its own identity issues. This experience has colored how I see the world and has instilled in me a desire to study identity politics.

Before beginning to write, I sought for a novel that would offer some perspective on Central Americans in the US. I found this task to be nearly impossible. Most of the "Latino/a” narratives were from the more established "Latino/a” groups: Mexican, Dominican, Puerto Rican and Cuban. I finally came across Francisco Goldman’s The Ordinary Seaman. Excited at the prospect of exploring a text “about me,” I diligently read to find that moment where I would say-Yes, that's me! However, as I read and researched I was surprised to see how this “Yes, that's me!” stemmed from my idea that sharing a nationality somehow meant that I could connect to some shared essence. I was wrong, and both Goldman’s text and my research let me know it.

I was not sure which route to take. At first, as a so-called "Latino" from Miami, I figured that I would speak about US Latino/a literary studies’ underrepresentation of Central America. While this was the overall purpose of my project, I steered away from 
concentrating simply on that. I figured that if I explored Central American narratives and treat them as I would treat other narratives—exploring complexities, reading against the grain, revealing the unexplored areas-I would be able to convince my reader that Central American and Central American-American narratives are an untapped source that greatly contribute to US Latino/a literary studies. However, I had been too modest. Central America proved to be much more complicated than I anticipated. As I hope to have demonstrated, the area is too vast, and identity politics are too complex to explore simply through a US "Latino/a" lens. That is why throughout my thesis I explored US intervention, revolutionary processes, and the hidden "blackness" within Central American narratives.

It was my intention to remind the reader and myself that Central American, Central American-American, Nicaraguan, Latino, Black, Caribbean, or any other identity does not tie one to some essential quality or experience. In following this idea, my thesis exposed the external and internal factors that constructed these allegedly stable and homogenous identities. For example, I showed how US Intervention, los letrados, and the revolutionary crisis in Central America contributed to the production of culture in Nicaragua and in Central America overall. The experience of relocating to a different space, the memory of a lost place and a revolutionary past, plus the erasure of a Central American identity within the US contact zone, an identity that is constructed in the first place, was perhaps the best way I could have expressed what I meant by Central American-American ways of seeing.

However, it was also of the upmost important to make visible the forgotten Nicaraguan Atlantic coast. While it is true that Central American narratives have been 
largely ignored within US "Latino/a" literary studies, the literary scholarship that does address the region mostly concerns itself with mestizaje and reads Central AmericanAmerican novels like Goldman’s text as “Latino/a” novels. As a result, my thesis was discussed how Central America contributes to black Atlantic scholarship, and I read The Ordinary as a black Atlantic text. Placed in conversation with my first chapter, the point I made in general was that categorizations, labels, western homogenization, and ideological projects in Central America, all work to silence the voice of ordinary people whether "mestizo" or "black." Ultimately, I hoped to have successfully deconstructed the myth of a "pure" mestizo and a "pure” black identity because I argue that racial and/or ethnic constructions take the focus away from the fact that "ordinary" people all share a common western oppressor.

For these reasons, my approach has been to read The Ordinary Seaman alongside the political and historical data that I offered. If it seems that at times I placed more emphasis on historically and geographically situating Nicaragua's cultural development and race relations, the reader would be right in assuming that. However, the reader should understand that it was vitally important to contextualize my reading of the novel. It was also necessary to offer as much historical and cultural background as possible because of Central America’s underrepresentation. My only regret was that time and space did not permit me to give more historical background and testimonies of people whose histories have remained silent for way too long.

I will end by saying that I have by no means exhausted the regions untapped potential. In future studies, I hope to include a feminist and queer Atlantic reading. I also will admit that the issue of language, bilingual aesthetics, and other studies that would 
incorporate other regions in the isthmus like Belize and Panama are vitally important to place in conversation with the work I presented here. Nevertheless, if the reader has gained anything at all from my thesis, I hope it has been that Central American ways of seeing merit scholarly attention and that the isthmus is an indispensable area to explore for any serious literary and black Atlantic scholar. 


\section{BIBLIOGRAPHY}

Anderson, Benedict R. O. Imagined Communities: Reflections on the Origin and Spread of Nationalism. Rev. and Extended ed. London: Verso, 1991. Print.

Arias, Arturo. Taking Their Word Literature and the Signs of Central America. Minneapolis: University of Minnesota, 2007. Print.

Alvador, Steven E., and Douglas S. Massey. "In Search of Peace: Structural Adjustment, Violence, and International Migration." Annals of the American Academy of Political and Social Science 630 (2010): 137-61. JSTOR. Web. 28 Jan. 2015.

Benitez-Rojo, Antonio. The Repeating Island: The Caribbean and the Postmodern Perspective. Durham: Duke University Press, 1992. Print.

Caminero-Santangelo, Marta. "Central Americans in the City: Goldman, Tobar, and the Question of Panethnicity.” Literature Interpretation Theory 20:3 (2009): 173-95. Taylor Francis Online. Web. 28 June 2014.

Casey, Edward S. "Between Geography and Philosophy: What Does It Mean to Be in the Place-World? Author(s): Edward S. Casey." Annals of the Association of American Geographers 91.4 (2001): 683-93. JSTOR. Web. 21 Apr. 2015.

Fanon, Frantz. Black Skin, White Masks. 1952. Trans. Richard Philcox. First ed. New York: Grove Press, 2008. Print.

Foucault, Michel, and Jay Miskowiec. "Of Other Spaces." Diacritics 16.1 (1986): 22-27. JSTOR. Web. 18 Apr. 2015.

"Francisco Goldman." Contemporary Authors Online. Detroit: Gale, 2012. Biography in Context. Web. 13 Sept. 2014.

Gilroy, Paul. The Black Atlantic: Modernity and Double Consciousness. Cambridge, Massachusetts: Harvard University Press, 1993. Print.

Goldman, Francisco. The Ordinary Seaman. New York: Atlantic Monthly, 1997. Print.

Gordon, Edmund T., and Mark Anderson. “The African Diaspora: Toward an Ethnography of Diasporic Identification.” The Journal of American Folklore 112.445 (1999): 282-96. JSTOR. Web. 3 May 2015.

Hanemann, Ulrike. “Nicaragua’s literacy campaign Education for All Global Monitoring Report 2006” UNESCO (2005): 1-11. Web. 29 Apr. 2015.

Henighan, Stephen. "Forged Testimonies: Fabricating the Nation in Sergio Ramírez's "Sombras nada más"." The Modern Language Review 102.3 (2007): 737-52. Academic OneFile. Web. 29 Apr. 2015. 
Hooker, Juliet. “'Beloved Enemies”: Race and Official Mestizo Nationalism in Nicaragua.” Latin American Research Review 40.3 (2005): 14-39. JSTOR. Web. 3 May 2015.

Lancaster, Roger N. “Skin Color, Race, and Racism in Nicaragua.” Ethnology 30.4 (1991): 339-53. JSTOR. Web. 3 May 2015.

Mahler, Sarah J., and Dusan Ugrina. "Central America: Crossroad of the Americas ." Migration Policy Institute. N.p., Apr. 2006. Web. 25 Jan. 2015.

$<$ http://www.migrationpolicy.org/article/central-america-crossroads-americas>

"Mandingo, n." The Oxford English Dictionary. OED Online. Oxford University Press. 30 April 2015.

“Martha, n.” The Oxford English Dictionary. OED Online. Oxford University Press. 30 April 2015.

McGarrity, Gail. "Contrasting Experiences of Blackness in Lowland Central America: The Case of Nicaragua.” Caribbean Quarterly 46.2 (2000): 45-66. JSTOR. Web. 11 May 2015.

Nancy, Jean-Luc. "The Technique of the Present." Nouveau Musée. Paris. Jan. 1997. Web. 29 Apr. 2015. <http://www.usc.edu/dept/complit/tympanum/4/nancy.html>.

Rodriguez, Ana Patricia. Dividing the Isthmus Central American Transnational Histories, Literatures, and Cultures. Austin: U of Texas, 2009. Print.

Rodriguez, Ana Patricia. "Refugees of the South: Central Americans in the U.S. Latino Imaginary.” American Literature 73.2 (June 2001):387-412. JSTOR. Web 1 July 2014.

Reuters. "Construction of Nicaragua Canal to Begin December 22: Committee." New York Times 20 Nov. 2014. Web. 12 Jan. 2015.

Sanchez, Luis. "Splitting the Country: The Case of the Atlantic Coast of Nicaragua." Journal of Latin American Geography 6.1 (2007): 7-23. Project Muse. Web. 3 May 2015.

Solaun, Mauricio. U.S. Intervention and Regime Change in Nicaragua. London: University of Nebraska Press, 2005. Print

Sommer, Doris. Bilingual Aesthetics: A New Sentimental Education. Durham: Duke University Press, 2004. Print. 
Trigg, Dylan. Introduction. The Memory of Place a Phenomenology of the Uncanny. Athens: Ohio UP, 2012. 1-42. Print. 